\title{
Unprepared root canal surface areas: causes, clinical implications, and therapeutic strategies
}

\section{José Freitas SIQUEIRA JUNIOR ${ }^{(a)}$ Isabela das Neves RÔÇAS(a) \\ Marília Fagury \\ MARCELIANO-ALVES(a) \\ Alejandro Ron PÉREZ(a) \\ Domenico RICUCCI (b)}

(a) Universidade Estácio de Sá, Faculty of Dentistry, Department of Endodontics, Rio de Janeiro, RJ, Brazil.

(b) Private practice, Cetraro, Italy.
Declaration of Interests: The authors certify that they have no commercial or associative interest that represents a conflict of interest in connection with the manuscript.

Corresponding Author: José Freitas Siqueira Junior E-mail: if_siqueira@yahoo.com

https://doi.org/10.1590/1807-3107bor-2018.vol32.0065

Submitted: May 04, 2018

Accepted for publication: May 29, 2018

Last revision: June 06, 2018

\begin{abstract}
Chemomechanical preparation is intended to clean, disinfect, and shape the root canal. This step is of utmost importance during treatment of infected teeth with apical periodontitis, because treatment outcome depends on how effectively the clinician eliminates bacteria, their products, and necrotic tissue that would serve as substrate for bacterial regrowth. Nonetheless, curvatures and complex internal anatomical variations of the root canal system can pose a high degree of difficulty in reaching these goals. In infected teeth, bacteria may persist not only in difficult-to-reach areas such as isthmuses, ramifications, dentinal tubules, and recesses from C-shaped or oval/flattened canals, but also in areas of the main canal wall that remain untouched by instruments. If bacteria withstand chemomechanical procedures, there is an augmented risk for post-treatment apical periodontitis. This article discloses the reasons why some areas remain unprepared by instruments and discusses strategies to circumvent this issue and enhance infection control during endodontic treatment/retreatment of teeth with apical periodontitis.
\end{abstract}

Keywords: Root Canal Preparation; Root Canal Therapy; Treatment Outcome; Periapical Periodontitis.

\section{Introduction}

Apical periodontitis is a disease of infectious etiology. ${ }^{1}$ Consequently, its successful treatment relies upon effective infection control. Chemomechanical preparation can be considered the most important phase of endodontic treatment, because, in addition to carving a shape for proper filling, it eliminates the cause of apical periodontitis - bacterial infection of the root canal. By mechanical and chemical means, bacteria and their products are eliminated from the canal, and necrotic tissue is removed, which might serve as substrate for bacterial regrowth. Healing of apical periodontitis is certainly more predictable when the intracanal bacterial burden is eradicated or at least substantially reduced (disinfection) to levels that are compatible with periradicular tissue repair. ${ }^{2}$

The main risk factor for post-treatment apical periodontitis is the poor quality of previous endodontic treatment. ${ }^{3,4,5,6}$ In most cases, technical deficiencies during chemomechanical procedures will result in insufficient cleaning and disinfection, leading to bacterial persistence in the canal. 
Levels of bacteria in poorly treated canals are expected to be sufficient to sustain periradicular inflammation.

However, although at a lower frequency, bacteria may persist even when treatment has followed acceptable standards. This occurs because the complexity of the root canal anatomy may pose significant challenges for attainment of proper cleaning, disinfection, and shaping, even for the experienced clinician. Anatomical complexities that may influence the results of chemomechanical procedures include curvatures, isthmuses, lateral canals, apical ramifications, and recesses from ovalshaped, C-shaped, or flattened root canals. Instruments act mainly on the main canal and proper cleaning and disinfection of isthmuses, recesses, and ramifications depend mostly on the chemical effects of irrigants and interappointment medicaments.

Even in the main canal, instruments have been shown not to reach all areas of the canal walls (Figure 1). ${ }^{78,9,10,11}$ This happens because of factors related to instrument features and/or canal anatomy. For instance, preparation based on final instruments that are smaller than the initial canal diameter is expected to leave more areas untouched. ${ }^{12}$ As for anatomy, a curvature introduces a complexity for instrumentation because the cutting action of the instruments along the curved canal is concentrated more on some walls than on others. ${ }^{13}$ Consequently, some areas may remain untouched by the instruments. ${ }^{7,814,15,16} \mathrm{In}$ addition, C-shaped and oval/flattened canals have an irregular morphology that is inconsistent with round preparations provided by rotary instrumentation systems (Figure 2). Therefore, unsurprisingly, canals with these morphologies exhibit a large amount of uninstrumented areas following preparation, $17,18,19,20,21$ as the instruments may not reach all recesses (Figure 2).

In small and/or round canals, micro-computed tomographic (micro-CT) studies have reported that different instrumentation systems leave approximately $10 \%$ to $50 \%$ of the full canal surface area unprepared (Figure 3) (Table 1). $.14,16,22,23,24,25,26,27,28,29,30,31,32,33,34,35,36,37$, ${ }^{38}$ These figures can be even higher when only the apical canal surface is evaluated (Table 1). As for oval/ flattened canals, the amount of untouched surface area after preparation has been shown to range from $10 \%$ to $80 \%$ (Table 2). ${ }^{17,27,39,40,41,42,43,44,45,46,47,48,49}$ This article discusses what happens to areas that remain unprepared, the implications of bacteria remaining in these areas, and strategies to improve root canal cleaning, shaping, and disinfection.

\section{Antimicrobial effects of preparation procedures}

Because bacterial elimination from the root canal has been regarded as a surrogate endpoint for treatment outcome, numerous studies have evaluated the antimicrobial efficacy of different instrumentation techniques and irrigation substances. Culture-dependent and culture-independent studies have shown that a substantial reduction in bacterial counts is obtained after chemomechanical preparation. $50,51,52,53,54,55,56$ The importance of using an antimicrobial substance such as sodium hypochlorite $(\mathrm{NaOCl})$ to supplement the mechanical effects of instrumentation and enhance root canal disinfection has been demonstrated by clinical ${ }^{51,57}$ and in vitro studies. ${ }^{58,59,60}$ Preparation using $2.5 \% \mathrm{NaOCl}$ as the irrigant can reduce bacterial levels $10^{2}$ to $10^{5}$-fold, with an overall reduction of $95 \%$ to $99 \% .58,61,62,63$ The best $\mathrm{NaOCl}$ antimicrobial effects are observed when the substance is regularly exchanged and used in large volumes. ${ }^{58}$ Chlorhexidine (CHX) has also been used for irrigation as an alternative to $\mathrm{NaOCl}$ and has shown similar antimicrobial results. ${ }^{56,62,64}$

Notwithstanding the pronounced bacterial reduction promoted by $\mathrm{NaOCl}$ or $\mathrm{CHX}$ in association with mechanical instrumentation, bacteria may still be detected in about $30 \%$ to $60 \%$ of the canals of teeth with apical periodontitis after preparation with these solutions. ${ }^{50,51,53,63,64,65,66,67,68,69,70,71,72}$ It is salient to point out that samples in most studies of this nature are taken with paper points placed in the main canal. Although bacteria located in areas in the immediate vicinity of the main canal can be sampled, the results from these studies are mostly related to the bacteriological conditions of the main canal lumen and walls.

The main question is: how can bacteria manage to avoid the mechanical effects of instruments and irrigation as well as the chemical effects of irrigants, even in the main canal? Mechanical debridement is a powerful means to remove biofilms from any surface. In infected canals, biofilms will only have chances to 

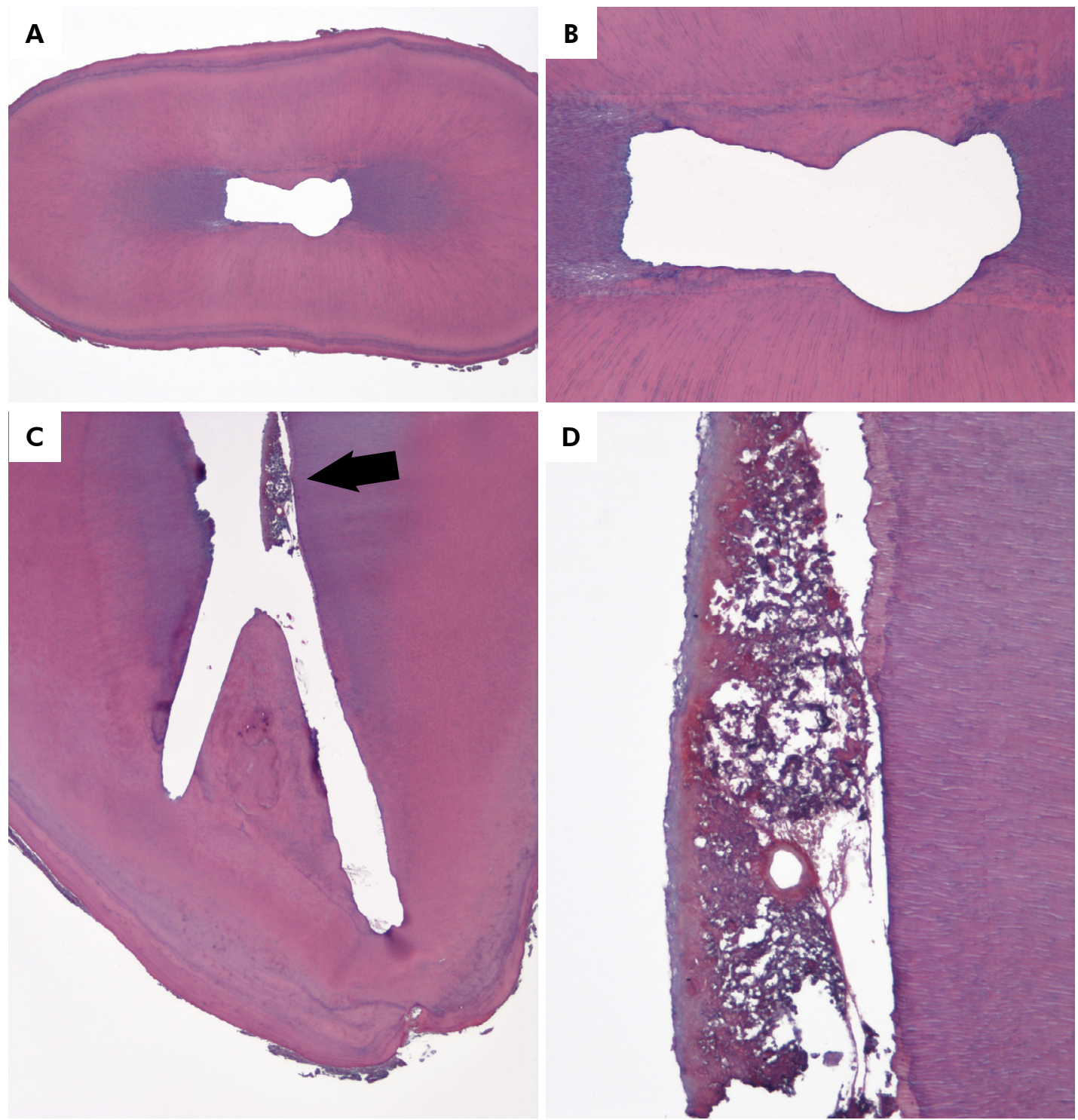

Figure 1. Extracted mandibular incisor subjected to ex vivo root canal instrumentation. (A) Cross section cut at the middle third. Only a fraction of the canal circumference was shaped by rotary instruments. The canal lumen appears free from soft tissue remnants (hematoxylin and eosin, original magnification $\times 16$ ). (B) Detail from (A) (original magnification $\times 50)$. (C) Longitudinal section of the apical third, encompassing the apical canal and a large apical ramification (original magnification $\times 16$ ). (D) Middle magnification of the canal area indicated by the arrow in (C). A large mass of pulp tissue remnants can be appreciated. Note that predentin is still present on the canal wall, confirming that the area was not touched by the instruments (original magnification $\times 100$ ).

remain if they occur in areas where the instruments do not exert their cutting action and irrigants fail to reach at an effective concentration and/or time. Thus, residual bacterial biofilms located in these areas would remain unaffected or be only partially eliminated, especially if they are thick (Figure 4).

Inefficiency of instruments and irrigants can be a result of inappropriate treatment. For instance, when apical preparation size is too small, large amounts of bacteria and necrotic tissue can be left behind. The same is expected when preparation is too short of the apex, leaving a large extent of unprepared main canal. Poor irrigation due to small volume of irrigant or shallow depth of needle penetration may also compromise cleaning and disinfection. 

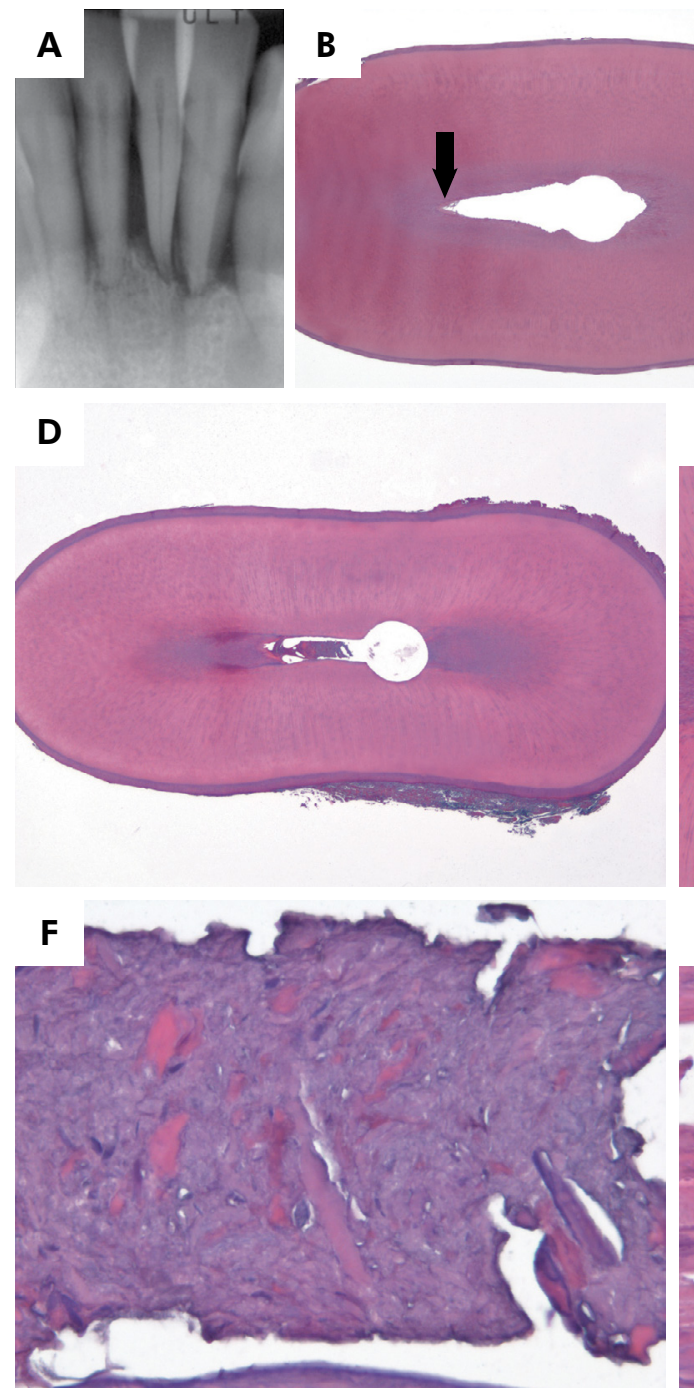

C
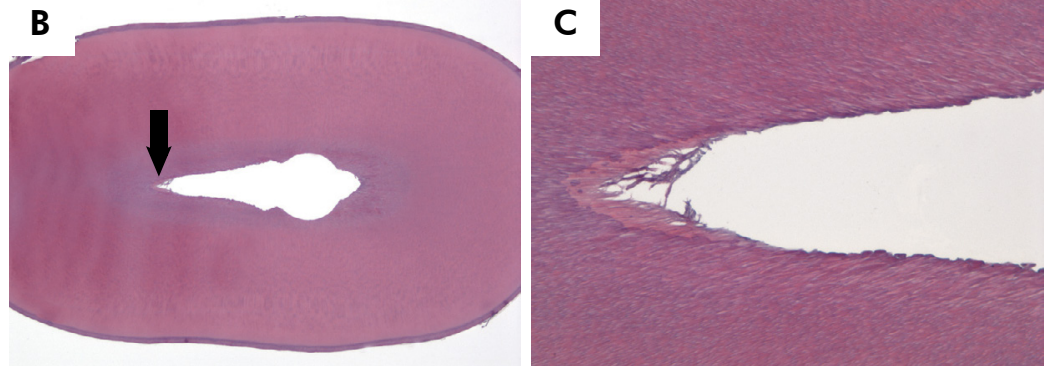

E

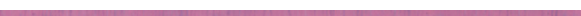

1.
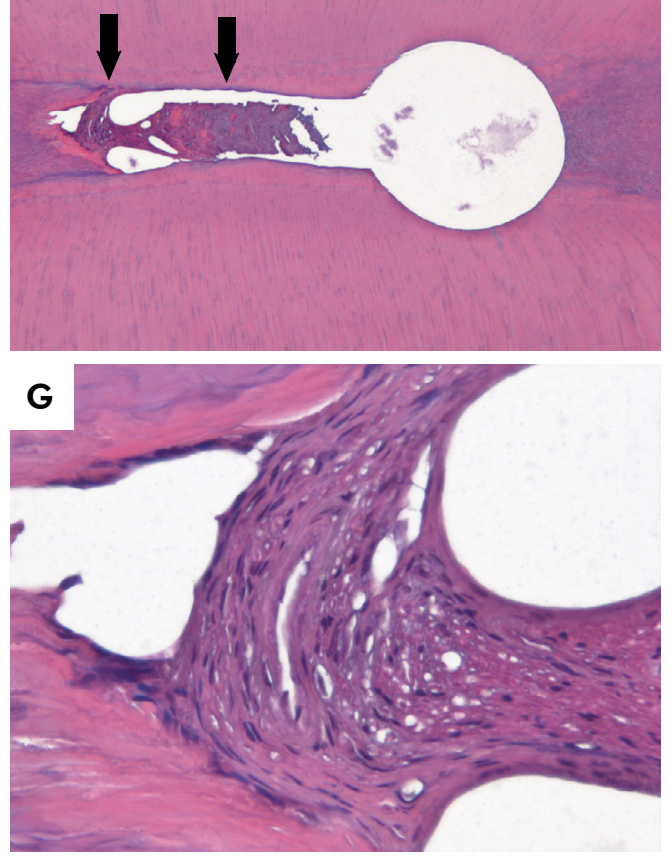

Figure 2. Mandibular incisors with advanced periodontal disease. Tooth 41 had indication for extraction and before that, with the patient's agreement, its root canal was instrumented with rotary NiTi instruments. (A) Preoperative radiograph. (B) Cross-cut section from the middle third of tooth 41 . The walls of the long oval canal were instrumented only on one side, to a minimal extent. Soft tissues are absent (haematoxylin and eosin, original magnification $\times 16$ ). (C) Magnification of the lingual extension of the canal, indicated by the arrow in (B). Predentin is still present, indicating that instruments had not reached this area, with a minimal amount of soft tissue debris (original magnification $\times 100$ ). (D) Cross section cut at the transition from middle to apical third. NiTi instruments shaped only one portion of the oval canal, while the majority of the canal walls appeared untouched, with the lumen filled with pulp tissue remnants (original magnification $\times 16$ ). (E) Detail from (D) (original magnification $\times 50$ ). (F) High power view of the area of the canal indicated by the right arrow in (E). Dentin filings enmeshed in a necrotic pulp tissue (original magnification $\times 400$ ). (G) High power view of the area of the canal indicated by the left arrow in $(E)$. Vital pulp tissue is present at some distance from the instrumented portion of the canal (original magnification $\times 400$ ).

As mentioned previously, there is an increased risk of root canal surface areas remaining unprepared if the canal is curved. Moreover, the use of reaming motion for preparation of oval/flattened or C-shaped canals often results in suboptimal cleaning and disinfection. $17,73,74,75,76,77,78$ Recesses that remain untouched by instruments may harbor residual biofilms and be packed with infected dentin debris (Figure 4). ${ }^{79,80,81}$

\section{Evaluating canal preparation with correlative approaches}

Root canal cleaning, shaping, and disinfection during preparation have been evaluated by numerous analytical approaches, depending on the parameter under assessment. For instance, cleaning studies have used histology, ${ }^{9,10,82,83}$ histobacteriology, ${ }^{8}$ and scanning 


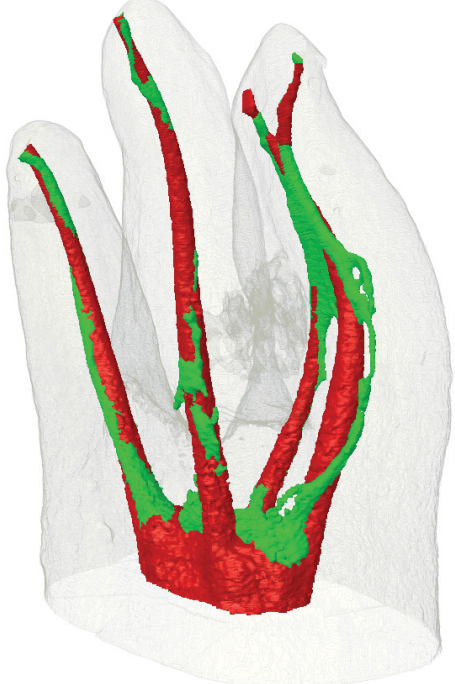

Figure 3. Superimposed micro-computed tomographic images taken before (green) and after (red) the use of rotary $\mathrm{NiTi}$ instruments revealing areas that remained unprepared (green). electron microscopy. ${ }^{11,84,85}$ Shaping studies have made use of radiographs, ${ }^{86,87}$ resin blocks, ${ }^{88,89}$ conebeam computed tomography, ${ }^{90}$ and micro-computed tomography (micro-CT). ${ }^{7,25}$ Studies evaluating disinfection have used histology/transmission electron microscopy, ${ }^{91}$ histobacteriology, ${ }^{8}$ culture, ${ }^{51,64,92}$ and molecular methods. ${ }^{52,55,93}$ Findings presented by these methods have been successfully used to elucidate the effects of chemomechanical procedures and improve instruments, irrigants, and techniques over the years.

Over the last decade, micro-CT has been certainly the most widely used methodology to investigate the shaping effects of instruments and instrumentation techniques. Its wide use and acceptance mostly refers to its nondestructive nature, which permits one to compare the root canal morphology before and after preparation using extracted teeth. Overlapping of

Table 1. Amount of uninstrumented areas after preparation of molar canals. Studies using micro-computed tomography

\begin{tabular}{|c|c|c|c|c|c|}
\hline Study & Tooth type & Instrument & $\begin{array}{c}\text { Area evaluated (full or } \\
\text { apical canal) }\end{array}$ & Uninstrumented area (\%) & Statistical findings \\
\hline \multirow{4}{*}{$\begin{array}{l}\text { Peters et al. } \\
(2001)^{7}\end{array}$} & \multirow{4}{*}{ Max M } & GT & Full canal & $43 \%$ & No significant differences \\
\hline & & Lightspeed & Full canal & $37.5 \%$ & \\
\hline & & NiTi Hand Files & Full canal & $35 \%$ & \\
\hline & & Profile & Full canal & $37 \%$ & \\
\hline \multirow{3}{*}{$\begin{array}{l}\text { Peters et al. } \\
(2001)^{25}\end{array}$} & \multirow{3}{*}{$\operatorname{Max} M$} & K-File & Full canal & $53.5 \%$ & No significant differences \\
\hline & & Lightspeed & Full canal & $39 \%$ & \\
\hline & & Profile & Full canal & $43 \%$ & \\
\hline \multirow{3}{*}{$\begin{array}{l}\text { Peters et al. } \\
(2003)^{32}\end{array}$} & Max M MB & PT & Full canal & $43 \%$ & No significant differences \\
\hline & Max M DB & PT & Full canal & $33 \%$ & \\
\hline & Max M P & PT & Full canal & $49 \%$ & \\
\hline \multirow{3}{*}{$\begin{array}{l}\text { Paqué et al. } \\
(2005)^{33}\end{array}$} & Max M MB & Endo-Eze & Full canal & $30 \%$ & No significant differences \\
\hline & Max M DB & Endo-Eze & Full canal & $25 \%$ & \\
\hline & Max M P & Endo-Eze & Full canal & $29 \%$ & \\
\hline \multirow{6}{*}{$\begin{array}{l}\text { Paqué et al. } \\
(2009)^{14}\end{array}$} & \multirow{6}{*}{$\operatorname{Max} M$} & Flexmaster & Full canal/apical canal & $\sim 43 \% / \sim 42 \%$ & $\begin{array}{c}\text { GT left significantly more } \\
\text { untreated areas }\end{array}$ \\
\hline & & GT & Full canal/apical canal & $\sim 44 \% / \sim 71 \%$ & \\
\hline & & Lightspeed & Full canal/apical canal & $\sim 42 \% / \sim 50 \%$ & \\
\hline & & NiTi Hand Files & Full canal/apical canal & $\sim 40 \% / \sim 50 \%$ & \\
\hline & & Profile & Full canal/apical canal & $\sim 40 \% / \sim 50 \%$ & \\
\hline & & PT & Full canal/apical canal & $\sim 42 \% / \sim 45 \%$ & \\
\hline \multirow{2}{*}{$\begin{array}{l}\text { Paqué et al. } \\
(2011)^{22}\end{array}$} & \multirow{2}{*}{ Mand M IV } & PT F2 reciprocating & Full canal/apical canal & $16 \% / 25 \%$ & No significant differences \\
\hline & & PT Full sequence & Full canal/apical canal & $19 \% / 30 \%$ & \\
\hline \multirow{3}{*}{$\begin{array}{l}\text { Peters and } \\
\text { Paqué }(2011)^{41}\end{array}$} & Max M MB & SAF & Full canal/apical canal & $26 \% / N S$ & No significant differences \\
\hline & Max M DB & SAF & Full canal/apical canal & $22 \% / 29 \%$ & \\
\hline & Max M P & SAF & Full canal/apical canal & $25 \% / 47 \%$ & \\
\hline
\end{tabular}

Continue 


\begin{tabular}{|c|c|c|c|c|c|}
\hline \multirow{2}{*}{$\begin{array}{l}\text { Yang et al. } \\
(2011)^{26}\end{array}$} & \multirow{2}{*}{ Mand M IV } & Mtwo & Full canal & $42 \%$ & No significant differences \\
\hline & & PTU & Full canal & $39 \%$ & \\
\hline \multirow{2}{*}{$\begin{array}{l}\text { Markvart et al. } \\
(2012)^{23}\end{array}$} & \multirow{2}{*}{$\begin{array}{l}\text { Max/Mand } \\
\text { M }\end{array}$} & GT/Profile & $\begin{array}{l}\text { Full canal/coronal } \\
\text { canal/middle canal/ } \\
\text { apical canal }\end{array}$ & $38 \% / 32 \% / 45 \% / 39 \%$ & No significant differences \\
\hline & & $\mathrm{RaCe} / \mathrm{NiTi}$ Hand Files & $\begin{array}{l}\text { Full canal/coronal } \\
\text { canal/middle canal/ } \\
\text { apical canal }\end{array}$ & $49 \% / 40.5 \% / 58.5 \% / 50 \%$ & \\
\hline \multirow{3}{*}{$\begin{array}{l}\text { Siqueira et al. } \\
(2013)^{16}\end{array}$} & \multirow{3}{*}{ Mand M IV } & Reciproc & Full canal & $21 \%$ & No significant differences \\
\hline & & SAF & Full canal & $33 \%$ & \\
\hline & & TF & Full canal & $25.5 \%$ & \\
\hline \multirow{3}{*}{$\begin{array}{l}\text { Zhao et al. } \\
(2013)^{34}\end{array}$} & \multirow{3}{*}{ Max M } & Hyflex CM & NS & $41 \%$ & No significant differences \\
\hline & & K3 & NS & $42 \%$ & \\
\hline & & TF & NS & $40 \%$ & \\
\hline \multirow{3}{*}{$\begin{array}{l}\text { Gergi et al. } \\
(2015)^{28}\end{array}$} & \multirow{3}{*}{ Mand M IV } & Reciproc & Full canal/apical canal & $20.5 \% / 25 \%$ & $\begin{array}{c}\text { Reciproc left significantly less } \\
\text { untreated areas }\end{array}$ \\
\hline & & TFA & Full canal/apical canal & $29 \% / 35.5 \%$ & \\
\hline & & WaveOne & Full canal/apical canal & $35 \% / 40 \%$ & \\
\hline \multirow{3}{*}{$\begin{array}{l}\text { Zhao et al. } \\
(2014)^{27}\end{array}$} & \multirow{3}{*}{$\begin{array}{l}\text { Mand M } \\
\text { MB; ML; D }\end{array}$} & PTN & NS & $41.5 \% ; 37 \% ; 55 \%$ & No significant differences \\
\hline & & PTU & NS & $41 \% ; 38 \% ; 56 \%$ & \\
\hline & & WaveOne & NS & $40 \% ; 35 \% ; 52 \%$ & \\
\hline \multirow{3}{*}{$\begin{array}{l}\text { De-Deus et al. } \\
(2015)^{35}\end{array}$} & \multirow{3}{*}{ Mand M II } & BR3; BR5 & Full canal & $\sim 45 / \sim 41$ & $\begin{array}{l}\text { Significant reduction in the } \\
\text { percentage of untreated areas } \\
\text { after larger preparation }\end{array}$ \\
\hline & & Reciproc 25/08; 40/06 & Full canal & $\sim 38 / \sim 43$ & \\
\hline & & WaveOne 25/08; 40/08 & Full canal & $\sim 45 / \sim 31$ & \\
\hline \multirow{3}{*}{$\begin{array}{l}\text { Gagliardi et al. } \\
(2015)^{36}\end{array}$} & \multirow{3}{*}{ Mand M IV } & PTG & Full canal & $3.5 \%$ & $\begin{array}{l}\text { PTN showed significantly } \\
\text { more untreated areas }\end{array}$ \\
\hline & & PTN & Full canal & $12 \%$ & \\
\hline & & PTU & Full canal & $3 \%$ & \\
\hline \multirow{2}{*}{$\begin{array}{l}\text { Peters et al. } \\
(2015)^{24}\end{array}$} & \multirow[t]{2}{*}{ Mand M IV } & $\begin{array}{c}\text { TruShape 20/06v; } \\
\text { 30/06v }\end{array}$ & Full canal/apical canal & $\begin{array}{c}28.5 \% ; 15 \% / 43.5 \% \\
19 \%\end{array}$ & $\begin{array}{l}\text { Enlargement to size \#30 } \\
\text { significantly increased the } \\
\text { amount of prepared area }\end{array}$ \\
\hline & & $\begin{array}{c}\text { Vortex Blue 20/06; } \\
\text { 30/06 }\end{array}$ & Full canal/apical canal & $19 \% ; 11 \% / 34 \% ; 19 \%$ & \\
\hline \multirow{2}{*}{$\begin{array}{l}\text { Alves et al. } \\
(2016)^{30}\end{array}$} & \multirow{2}{*}{ Mand M IV } & $\mathrm{BR}+\mathrm{PUI}$ & Full canal & $4 \%$ & No significant differences \\
\hline & & $B R+X p$ Endo Finisher & Full canal & $4.5 \%$ & \\
\hline \multirow{2}{*}{$\begin{array}{l}\text { Limoeiro et al. } \\
(2016)^{29}\end{array}$} & \multirow{2}{*}{ Mand M IV } & $\mathrm{BR}$ & Full canal & $12 \%$ & No significant differences \\
\hline & & PTN & Full canal & $15.5 \%$ & \\
\hline \multirow{2}{*}{$\begin{array}{l}\text { Brasil et al. } \\
(2017)^{37}\end{array}$} & \multirow{2}{*}{ Mand M IV } & BTR & Full canal/apical canal & $33 \% / 14 \%$ & No significant differences \\
\hline & & PTN & Full canal/apical canal & $31 \% / 14 \%$ & \\
\hline \multirow[t]{2}{*}{$\begin{array}{l}\text { Duque et al. } \\
(2017)^{38}\end{array}$} & \multirow[t]{2}{*}{ Mand M IV } & PTG F2/F3 & Full canal & $10 \% / 6 \%$ & $\begin{array}{l}\text { Significant reduction in the } \\
\text { percentage of untreated areas } \\
\text { after larger preparation }\end{array}$ \\
\hline & & PTU F2/F3 & Full canal & $6 \% / 5 \%$ & \\
\hline $\begin{array}{l}\text { Siqueira et al. } \\
(2018)^{31}\end{array}$ & Mand M IV & Reciproc & Full canal/apical canal & $18 \% / 10 \%$ & NC \\
\hline
\end{tabular}

Max M: maxillary molars; Max M IV: Maxillary molars mesiobuccal canals Vertucci's type IV; Mand M IV: Mandibular molars mesial canals Vertucci's type IV; Mand M II: Mandibular molars mesial canals Vertucci's type II; MB: Mesiobuccal canal; DB: Distobuccal canal; ML: Mesiolingual canal; D: Distal canal; P: Palatal canal; NS: Not specified; NC: No intergroup/intragroup comparison; BR: BioRaCe; BTR: BT-Race; GT: Greater taper; PT: ProTaper; PTG: ProTaper Gold; PTN: ProTaper Next; PTU: ProTaper Universal; SAF: Self-Adjusting Flle; TF: Twisted file; TFA: Twisted File Adaptive 

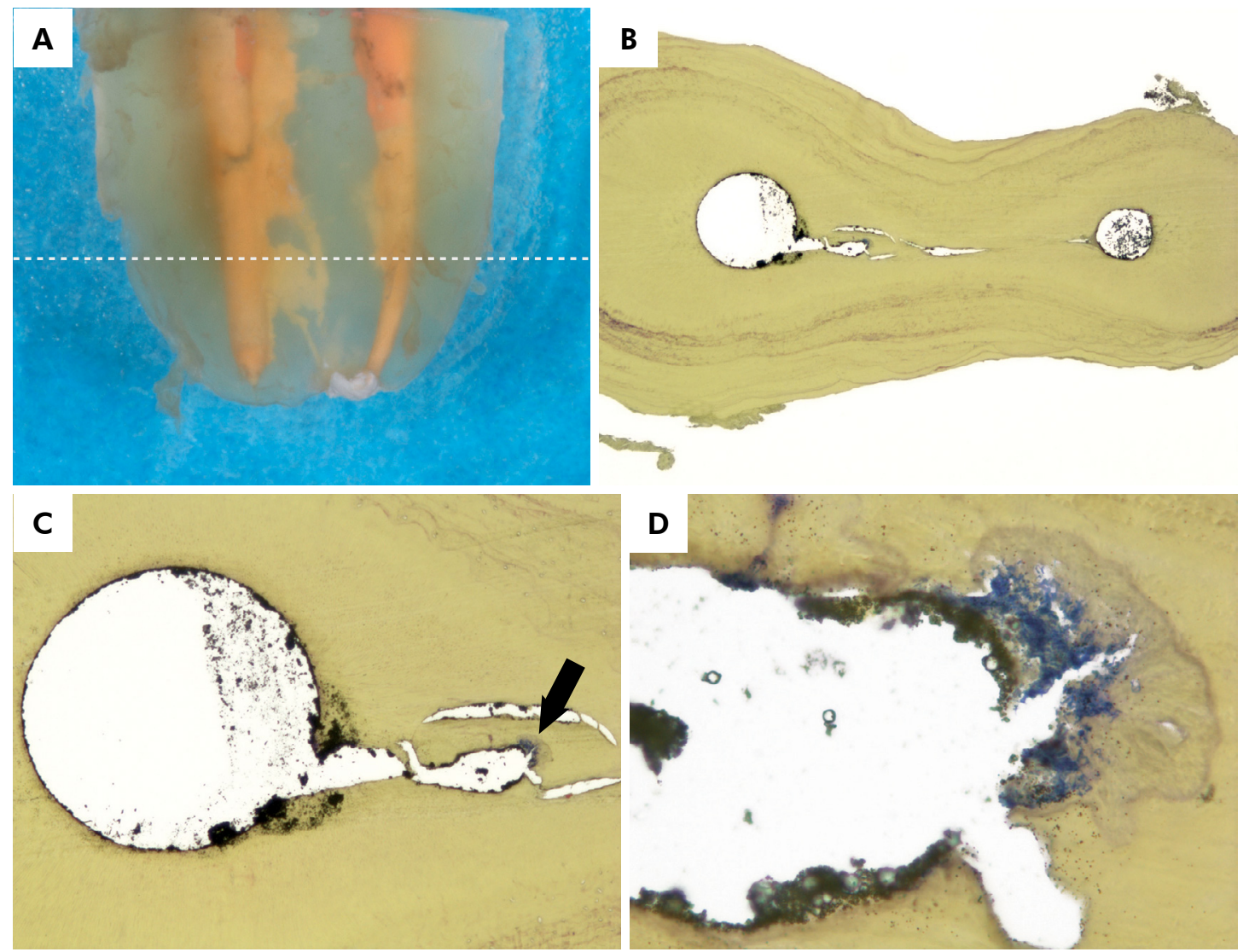

Figure 4. Experimental root canal treatment performed in vivo on a non-restorable mandibular molar, as part of a study and under the patient agreement. Mesial canals were instrumented and obturated in one visit. The tooth was extracted after one week. (A) Mesial root in the clearing agent at the end of the demineralization process, just before paraffin infiltration. (B) Cross section cut at the level of the line in (A). The overview shows an irregular isthmus at this level (Taylor's modified Brown \& Brenn, original magnification $\times 16$ ). (C) Detail of the left canal in (B) (original magnification $\times 50$ ). (D) High power view of the area of the isthmus indicated by the arrow in (C). A thick bacterial biofilm fills an irregular space and is layered by obturation material (original magnification $\times 400$ ).

images taken before and after the use of instruments reveals areas that remained uninstrumented (Figure3). Numerous studies have shown that an overall large surface area of the canal remains unprepared, regardless of the instrument used, and this is still more critical in curved and/or oval/flattened canals. ${ }^{16,22,23,24}$

As discussed above, uninstrumented areas may potentially harbor remnants of bacterial biofilms. ${ }^{16,27}$ One might assume that even if the instruments fail to reach all canal walls, these areas would be permeated by $\mathrm{NaOCl}$ used for irrigation, which could dissolve necrotic tissue remnants and kill residual bacteria. In this case, the irrigant should reach the uninstrumented areas at an effective concentration and volume and remain therein long enough for it to take effect.
Studies have evaluated only one parameter at a time, i.e., either the amount of untouched walls or the cleaning/disinfection effects of preparation. Recently, several studies have been conducted by our group to investigate what happens to the uninstrumented surface areas by using a correlation between micro-CT and another analytical method for cleaning or disinfection (Figure 5).

In the first study, ${ }^{16}$ we combined findings from micro-CT and microbiological methods for a correlative evaluation of the effects of canal preparation using different instrumentation systems. Findings revealed no correlation between the amount of unprepared surface areas and residual bacterial levels. 
Table 2. Amount of uninstrumented areas after preparation of oval canals. Studies using micro-computed tomography

\begin{tabular}{|c|c|c|c|c|c|}
\hline Study & $\begin{array}{l}\text { Tooth } \\
\text { type }\end{array}$ & Instrument & $\begin{array}{c}\text { Area evaluated (full or apical } \\
\text { canal) }\end{array}$ & $\begin{array}{l}\text { Uninstrumented } \\
\text { area (\%) }\end{array}$ & Statistical findings \\
\hline \multirow{4}{*}{$\begin{array}{l}\text { Paqué et al. } \\
(2010)^{17}\end{array}$} & \multirow{4}{*}{$\begin{array}{l}\text { Mand } \\
\text { M D }\end{array}$} & PT1 & Full canal/apical canal & $80 \% / 69 \%$ & $\begin{array}{c}\text { PT1 left significantly more } \\
\text { untreated areas than PT2 in the } \\
\text { full canal }\end{array}$ \\
\hline & & PT2 & Full canal/apical canal & $60 \% / 65 \%$ & \\
\hline & & PT-CF & Full canal/apical canal & NS/65\% & \\
\hline & & $\mathrm{H}-\mathrm{CF}$ & Full canal/apical canal & NS/75\% & \\
\hline \multirow[t]{2}{*}{$\begin{array}{l}\text { Paqué and } \\
\text { Peters }(2011)^{42}\end{array}$} & \multirow[t]{2}{*}{$\begin{array}{l}\text { Mand } \\
\text { MD }\end{array}$} & SAF $1.5 \mathrm{~mm}$ & Full canal/apical canal & $23 \% / 40 \%$ & $\begin{array}{l}\text { SAF resulted in less untreated } \\
\text { surface for both full and apical } \\
\text { canal }\end{array}$ \\
\hline & & PT-2 & Full canal/apical canal & $60 \% / 65 \%$ & \\
\hline $\begin{array}{l}\text { Peters and } \\
\text { Paqué }(2011)^{41}\end{array}$ & $\begin{array}{l}\operatorname{Max} M \\
M B\end{array}$ & SAF $1.5 \mathrm{~mm}$ & Full canal/ apical canal & $26 \% / \mathrm{NS}$ & No significant differences \\
\hline \multirow[t]{2}{*}{$\begin{array}{l}\text { Versiani et al. } \\
(2011)^{40}\end{array}$} & \multirow[t]{2}{*}{$\begin{array}{l}\text { Mand } \\
\text { Inc }\end{array}$} & K3 & Coronal/middle/apical & $38 \% / 56 \% / 25 \%$ & $\begin{array}{l}\text { K3 left significantly more } \\
\text { untreated areas than SAF in } \\
\text { coronal and middle thirds }\end{array}$ \\
\hline & & SAF $1.5 \mathrm{~mm}$ & Coronal/middle/apical & $8 \% / 35 \% / 15 \%$ & \\
\hline \multirow{3}{*}{$\begin{array}{l}\text { Zhao et al. } \\
(2014)^{27}\end{array}$} & \multirow{3}{*}{$\begin{array}{l}\text { Mand } \\
\text { M IV }\end{array}$} & WaveOne & Full canal MB/ML & $40 \% / 35 \%$ & No significant differences \\
\hline & & PTN & Full canal MB/ML & $41.5 / 37 \%$ & \\
\hline & & PTU & Full canal MB/ML & $41 \% / 38 \%$ & \\
\hline \multirow[t]{2}{*}{$\begin{array}{l}\text { Busquim et al. } \\
(2015)^{39}\end{array}$} & \multirow[t]{2}{*}{$\begin{array}{l}\text { Mand } \\
\text { M D }\end{array}$} & $\mathrm{BR}$ & Full canal/coronal/middle/apical & $10 \% / 8 \% / 11 \% / 10 \%$ & $\begin{array}{l}\text { Reciproc left significantly more } \\
\text { untreated areas than BR5 in full, } \\
\text { coronal and middle canal }\end{array}$ \\
\hline & & Reciproc & Full canal/ coronal/middle/apical & $15 \% / 18 \% / 22 \% / 5 \%$ & \\
\hline \multirow{2}{*}{$\begin{array}{l}\text { Stavileci et al. } \\
(2015)^{43}\end{array}$} & \multirow{2}{*}{ Max PM } & PT & Coronal/middle/apical & $26 \% / 35 \% / 20 \%$ & $\begin{array}{c}\text { SS left significantly more untreated } \\
\text { areas than PT in all thirds }\end{array}$ \\
\hline & & SS & Coronal/middle/apical & $29 \% / 41 \% / 25 \%$ & \\
\hline \multirow{3}{*}{$\begin{array}{l}\text { Coelho et al. } \\
(2016)^{44}\end{array}$} & \multirow{3}{*}{$\begin{array}{l}\text { Mand } \\
\text { Inc }\end{array}$} & Easy Prodesign & Coronal/middle/apical & $64 \% / 62 \% / 70 \%$ & No significant differences \\
\hline & & OneShape & Coronal/middle/apical & $79 \% / 72 \% / 75 \%$ & \\
\hline & & WaveOne & Coronal/middle/apical & $80 \% / 77 \% / 75 \%$ & \\
\hline \multirow{2}{*}{$\begin{array}{l}\text { Arias et al. } \\
(2017)^{48}\end{array}$} & \multirow{2}{*}{$\begin{array}{l}\text { Mand } \\
\text { M D }\end{array}$} & TRUShape & Full canal/ apical canal & $56 \% / 50 \%$ & No significant differences \\
\hline & & Vortex Blue & Full canal/ apical canal & $51 \% / 51 \%$ & \\
\hline \multirow{2}{*}{$\begin{array}{l}\text { Espir et al. } \\
(2017)^{45}\end{array}$} & \multirow{2}{*}{$\begin{array}{l}\text { Mand } \\
\text { Inc }\end{array}$} & Mtwo & Full canal/coronal/middle/apical & $17 \% / 5 \% / 7 \% / 4 \%$ & No significant differences \\
\hline & & Reciproc & Full canal/coronal/middle/apical & $18 \% / 3 \% / 6 \% / 4 \%$ & \\
\hline \multirow[t]{2}{*}{$\begin{array}{l}\text { Guimarães et } \\
\text { al. }(2017)^{47}\end{array}$} & \multirow[t]{2}{*}{$\begin{array}{l}\text { Mand } \\
\text { PM }\end{array}$} & Reciproc & Full canal/ apical canal & $24 \% / 25 \%$ & $\begin{array}{c}\text { In the full canal Reciproc left } \\
\text { significantly more untreated areas } \\
\text { than TRUShape }\end{array}$ \\
\hline & & TRUShape & Full canal/apical canal & $30 \% / 20 \%$ & \\
\hline \multirow{4}{*}{$\begin{array}{l}\text { Lacerda et al. } \\
(2017)^{49}\end{array}$} & \multirow{4}{*}{$\begin{array}{l}\text { Mand } \\
\text { M D }\end{array}$} & SAF & Full canal/ apical canal & $11 \% / 10 \%$ & $\begin{array}{c}\text { In the apical third SAF left } \\
\text { significantly less untreated areas } \\
\text { than Xp Endo Shaper }\end{array}$ \\
\hline & & TRUShape & Full canal/anical canal & $175 \% / 16 \%$ & $\begin{array}{c}\text { No significant differences with } \\
\text { TRUShape }\end{array}$ \\
\hline & & IRUSnape & rell canai/apical camal & (17.5\%/10\% & $\begin{array}{l}\text { No significant differences in the } \\
\text { full canal }\end{array}$ \\
\hline & & Xp Endo Shaper & Full canal/apical canal & $17 \% / 18 \%$ & \\
\hline \multirow{4}{*}{$\begin{array}{l}\text { Zuolo et al. } \\
(2017)^{46}\end{array}$} & \multirow{4}{*}{$\begin{array}{l}\text { Mand } \\
\text { Inc }\end{array}$} & BR & NS & $32 \%$ & $\begin{array}{l}\text { BR left significantly more untreated } \\
\text { areas than Reciproc and SAF }\end{array}$ \\
\hline & & Reciproc & NS & $19 \%$ & $\begin{array}{c}\text { No significant differences with } \\
\text { TRUShape }\end{array}$ \\
\hline & & SAF & NS & $16 \%$ & \\
\hline & & TRUShape & NS & $19 \%$ & \\
\hline
\end{tabular}

Max M: Maxillary molars; Max M MB: Maxillary molars mesiobuccal canal; Max PM: Maxillary premolars Mand M D: Mandibular molars distal canal; Mand Inc: Mandibular incisors; Mand PM: Mandibular premolars; Mand M IV: Mandibular molars mesial canals Vertucci's type IV; NS: Not specified; BR: BioRaCe; CF: Circumferential filing; GT: Greater Taper; H: Hedström files; PT: ProTaper; PTG: ProTaper Gold; PTN: ProTaper Next; PTU: ProTaper Universal; SAF: Self-Adjusting File; SS: Stainless-steel hand files 
In another micro-CT/microbiology correlative study, Alves et al. ${ }^{30}$ evaluated the supplementary disinfecting ability of passive ultrasonic irrigation (PUI) and XP-endo Finisher in the mesial canals of mandibular molars. Teeth were anatomically matched between groups based on micro-CT parameters, the canals were contaminated, instrumented using $\mathrm{NaOCl}$ irrigation, and the supplementary approaches were used. Samples were taken from the main canal and from the isthmus area identified by micro-CT and processed by cryopulverization. Quantitative polymerase chain reaction analysis demonstrated that both supplementary approaches resulted in a small additional bacterial reduction, which was significant only for XP-Endo Finisher. Confirming the previous study, ${ }_{1}^{16}$ correlative analysis revealed no relationship between the amount of unprepared surface area and residual bacterial counts. Molecular microbiology analysis of the cryopulverized root fragments corresponding to the isthmus area showed no effective disinfection with either approach. ${ }^{30}$

A correlative study using micro-CT and histology or SEM evaluated what happens to canal walls of necrotic and vital teeth that remained uninstrumented following preparation with a reciprocating instrument and $\mathrm{NaOCl}$ irrigation. ${ }^{31}$ The unprepared surface areas were identified by micro-CT and their morphological conditions were examined microscopically. Overall, in the vast majority of specimens, the unprepared areas were covered with bacteria and/or remnants of pulp tissue.

Another recent study evaluated the cleaning and shaping ability of three instrumentation systems in oval canals using a correlative micro-CT/histological approach.$^{49}$ Canals matched by anatomic similarities were prepared by using SAF, TRUShape, and XP-endo Shaper instruments, with $5.25 \% \mathrm{NaOCl}$ irrigation. No significant difference was found for the amount of unprepared surface areas between the three instrument systems, except when comparing SAF and XP-endo Shaper in the apical canal (the former was better). No difference was found in the cleaning ability either, with about half of the specimens still exhibiting pulp remnants in some uninstrumented buccal and lingual recesses.
These correlative studies demonstrated that unprepared canal surfaces and isthmuses are not predictably cleaned and disinfected by conventional irrigation with $\mathrm{NaOCl}$. The ability of bacteria to persist in these areas and influence the treatment outcome depends on some factors.

\section{When bacteria persisting in unprepared areas influence the treatment outcome}

Persistent intraradicular infection is the most common cause of post-treatment apical periodontitis. ${ }^{2}$ For bacteria to withstand the effects of root canal treatment, they need to resist intracanal disinfection procedures, and adapt to the drastically changed environment. Although some bacteria may be resistant to some antimicrobial substances used in endodontics, ${ }^{94,95}$ the main reason for bacterial persistence is the inability of current techniques and medications to disinfect the entire extent of the root canal system.

In addition to enduring antimicrobial treatment, residual bacteria need to adapt to the drastically changed environment in order to survive and sustain periradicular inflammation. ${ }^{96}$ The whole ecology of the endodontic microenvironment is altered by treatment, so the surviving bacteria need to adapt to the new conditions.

Finding a source of nutrients is an essential prerequisite for bacterial survival. Remaining bacteria may utilize necrotic tissue remnants in untouched areas, recesses, isthmuses, and lateral canals as substrate, which is, however, a finite source. A sustainable nutrient source should exist and may develop as tissue fluids and inflammatory exudates from the periradicular tissues seep into the canal as a consequence of an inappropriate apical seal or a too short apical preparation/obturation. ${ }^{96}$ In most teeth with post-treatment disease, bacteria are located in the apical part of the root canal system, usually in the main canal lumen interposed between the filling material and the periapical tissues, in unprepared and unsealed areas and/or within apical ramifications..$^{97,98,99}$ In these locations, residual bacteria have easy access to nutrients. 
A

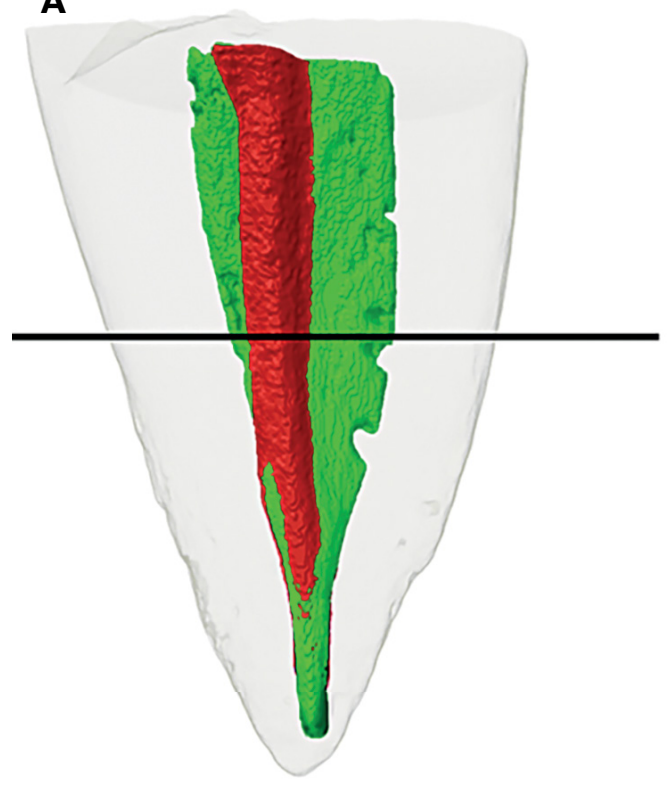

B

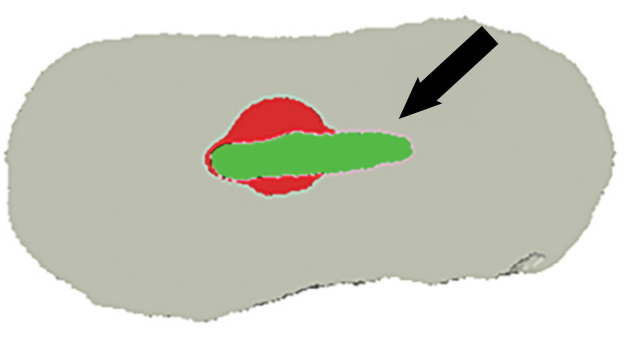

C

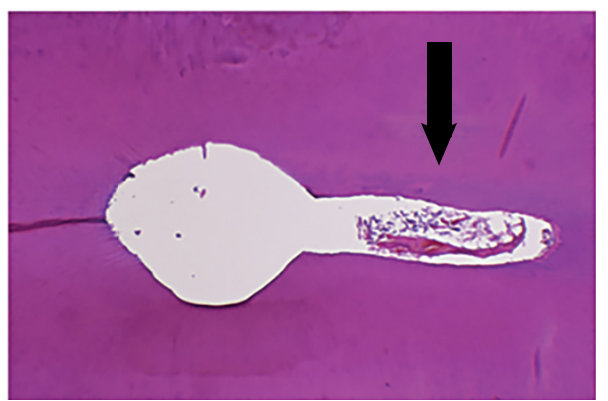

Figure 5. (A) Representative 3D reconstruction of micro-computed tomographic scans taken before (green) and after (red) root canal preparation with a rotary $\mathrm{NiTi}$ instrument showing unprepared areas (green). (B) Representative cross-section of the middle third region marked in (A), showing an unprepared recess (arrow). (C) Correlative histological section revealing pulp tissue remnants in the recess (arrow).

Persistent bacteria influence the endodontic treatment outcome when:

a. they withstand periods of nutrient deprivation immediately after chemomechanical procedures, scavenging for traces of nutrients and/or assuming a dormant state, to prosper again when a sustainable nutrient source is reestablished;

b. they adapt to the new ecological conditions of the canal, including oxygen tension, types of nutrient available, and co-existing species, all changed by treatment procedures;

c. they reach critical numbers to cause damage and stimulate inflammation in the periradicular tissues;

d. they have unrestrained access to the periradicular tissues through apical/lateral foramina or iatrogenic perforations;

e. they release virulence factors that are expressed in the modified environment and reach sufficiently high concentrations to sustain inflammation.

\section{Future challenge - reducing unprepared areas and/or improving disinfection}

Morphological studies of teeth with post-treatment apical periodontitis (endodontic treatment failure) have reported the occurrence of persistent bacterial infection in isthmuses, ${ }^{97,99,100}$ lateral canals and apical ramifications, ${ }^{97,98,100,101,102,103}$ recesses, ${ }^{97}$ and dentinal tubules. ${ }^{97,100,104}$ Current instrumentation systems fail to predictably touch all canal walls and reach these areas distant from the main canal. Therefore, there is an urgent need to develop strategies to improve infection control not only in the main canal lumen, but also in the entire root canal system.

Apparently, a logical strategy to reduce the amount of unprepared areas is to increase the size of apical preparation. Chemomechanical procedures should be considered complete when the canal is enlarged to instrument sizes that are compatible with the root anatomy and size, and sufficiently large to be safe and antibacterially effective. A micro-CT 
study demonstrated that after each increase in apical preparation size, the amount of unprepared surfaces reduced significantly. ${ }^{12}$ Microbiological studies have revealed that the larger the apical preparation size of infected canals, the greater the intracanal bacterial reduction. ${ }^{50,51,57,105,106,107,108,109,110}$ Moreover, the disinfecting benefits of $\mathrm{NaOCl}$ are significantly more evident in large apical preparation sizes. ${ }^{51,57}$ Studies have also shown that the larger the apical preparation size, the cleaner the apical canal. ${ }^{111,112}$ Larger preparations are also associated with improved outcome of the treatment of infected teeth with apical periodontitis. ${ }^{113,114}$

It is salient to point out that the width of canal preparation should be large enough in the apical portion to optimize disinfection and cleaning and at the same time not be too large so as not to cause accidents (ledges or perforation) or weaken the root. Overenlargement of the coronal part of the canal is undesirable, in order not to predispose to fracture. ${ }^{115}$ Instruments with variable tapers have been introduced (Reciproc, WaveOne, ProTaper, etc) and help deal with this issue, i.e., they permit large apical preparations, reducing unnecessary coronal enlargement.

Another strategy that has been widely recommended is to supplement the effects of chemomechanical procedures and enhance disinfection. Application of an interappointment medicament has been consistently shown to improve bacterial elimination after preparation, ${ }^{8,50,51,72,116}$ but efforts have been expended towards developing intravisit antimicrobial supplementary approaches that could obviate the need for an interappointment medicament.

Optimized single-visit disinfection (OSD) approaches that supplement the effects of chemomechanical procedures include final canal rinse with $\mathrm{CHX}$, mechanical, sonic, or ultrasonic activation of $\mathrm{NaOCl}$, photodynamic therapy (PDT), and photon-induced photoacoustic streaming (PIPS) using Er:YAG laser energy at subablative power levels (Fotona, Ljubljana, Slovenia). ${ }^{117}$

Mechanical, sonic, or ultrasonic activation of $\mathrm{NaOCl}$ following preparation has been recommended. Mechanical activation of $\mathrm{NaOCl}$ associated with a new supplementary instrument - XP-endo Finisher - has shown good results in terms of enhancing disinfection, ${ }^{30}$ but cannot predictably disinfect the isthmus area of molars. ${ }^{30,118}$ Sonic activation has shown no significant additional antimicrobial benefits. ${ }^{72}$ PUI is probably one of the most widely used supplementary approaches to optimize disinfection. Data from in vitro studies on PUI are rather inconclusive. ${ }^{119,120,121,122} \mathrm{Clinical}$ trials reported no significant supplementary antibacterial effects of PUI. ${ }^{123,124}$ Moreover, an outcome study found no superior results for treatment using PUI. ${ }^{125}$ Clinical studies on the antibacterial benefits of a final rinse with CHX have also shown inconclusive results. ${ }^{71,16,126}$ So far, there is no consistent information from clinical studies about the antibacterial effectiveness of PDT and PIPS.

There are also OSD strategies that serve as an alternative to conventional chemomechanical procedures and include instruments especially designed to adjust to the root canal anatomy, the EndoVac system for negative pressure irrigation, and the GentleWave multisonic wave system (Sonendo, Laguna Hills, CA, USA).

The new instruments devised to deal with canals of irregular shapes include the Self-Adjusting File (SAF) system (ReDentNOVA, Ra'anana, Israel), TRUShape (Dentsply Sirona, Tulsa, OK, USA), and XP-endo Shaper (FKG, La Chaux-de-Fonds, Switzerland). The latter two are very recent and there are no studies so far that have consistently evaluated their disinfecting ability in anatomically complex canals. In terms of cleaning, a study showed no significant difference between SAF, TRUShape, and XP-endo Shaper in oval canals. ${ }^{49}$ The SAF system, in turn, has been extensively studied and seems to promote better cleaning, shaping, and disinfection of oval/flattened canals than do conventional rotary instruments. ${ }^{40,127,128,129}$ SAF has been shown to leave fewer untouched areas in oval canals: from $6 \%$ to $35 \%{ }^{16,40,41,42,130}$ Nevertheless, the SAF instrument performance is similar to that of conventional rotary NiTi instruments in round, narrow, and non-complicated canals. ${ }^{16,124}$

The EndoVac system was shown by a clinical study not to significantly improve disinfection in comparison with conventional needle irrigation. ${ }^{131}$ As for the GentleWave system, there is no clinical study evaluating its antibacterial effectiveness. 
Placement of a well-adapted filling material along the entire extent of the prepared canal may also help deal with the issue of unprepared surface areas. Entombed by the filling material, bacteria on unprepared surfaces may succumb. Actually, because bacterial persistence in the canal is a risk factor for a poor treatment outcome, entombment is not reliable. ${ }^{132,133,134,135}$ In addition, bacteria in canal walls in contact with filling materials have been observed in some teeth with post-treatment apical periodontitis. ${ }^{97}$ Endodontic sealers usually exhibit some discrete antibacterial effects, but only before setting. ${ }^{136,137,138,139}$ Therefore, they should not be expected to significantly improve disinfection. In addition, because virtually no endodontic filling materials can promote a predictable antibacterial seal of the root canal, ${ }^{140,141,142,143,44,145}$ there will be instances when tissue fluids may leak into the canal and provide residual bacteria with nutrients. It is unclear whether leakage happens because not all walls were covered by sealer during obturation procedures or the sealer solubilized over time, resulting in a space fluids can leak into. ${ }^{104}$ Improvements in endodontic filling materials with better physicochemical features and antibacterial activity should be encouraged.

\section{References}

1. Kakehashi S, Stanley HR, Fitzgerald RJ. The effects of surgical exposures of dental pulps in germfree and conventional laboratory rats. Oral Surg Oral Med Oral Pathol. 1965 Sep;20(3):340-9. https://doi.org/10.1016/0030-4220(65)90166-0

2. Siqueira Junior JF, Rôças IN. Clinical implications and microbiology of bacterial persistence after treatment procedures. J. Endod. 2008; 34(11):1291-301.e3. https://doi.org/10.1016/j.joen.2008.07.028

3. Tronstad L, Asbjørnsen K, Døving L, Pedersen I, Eriksen HM. Influence of coronal restorations on the periapical health of endodontically treated teeth. Endod Dent Traumatol. 2000 Oct;16(5):218-21. https://doi.org/10.1034/j.1600-9657.2000.016005218.x

4. Moreno JO, Alves FR, Gonçalves LS, Martinez AM, Rôças IN, Siqueira Junior JF. Periradicular status and quality of root canal fillings and coronal restorations in an urban Colombian population. J Endod. 2013 May;39(5):600-4. https://doi.org/10.1016/i.joen.2012.12.020

\section{Conclusions}

There is no consistent clinical evidence showing that OSD approaches can predictably reduce the bacterial bioburden to levels significantly below those achieved by conventional chemomechanical procedures. Some approaches still need to be tested. In addition to randomized clinical trials for evaluating the performance of many available systems and protocols, it is also important to use a correlation of analytical methods in ex vivo studies to better evaluate the cleaning and disinfecting effects of endodontic procedures in unprepared canal walls and difficult-to-reach areas. The development of systems, techniques, and strategies to improve cleaning and disinfection of untouched canal walls and difficult-to-reach areas should be encouraged with the purpose of improving the treatment outcome.

\section{Acknowledgements}

This study was supported by grants from Fundação Carlos Chagas Filho de Amparo à Pesquisa do Estado do Rio de Janeiro (FAPERJ) and Conselho Nacional de Desenvolvimento Científico e Tecnológico (CNPq), Brazilian governmental institutions.

5. Hommez GM, Coppens CR, De Moor RJ. Periapical health related to the quality of coronal restorations and root fillings. Int Endod J. 2002 Aug;35(8):680-9. https://doi.org/10.1046/j.1365-2591.2002.00546.x

6. Tavares PB, Bonte E, Boukpessi T, Siqueira Junior JF, Lasfargues JJ. Prevalence of apical periodontitis in root canal-treated teeth from an urban French population: influence of the quality of root canal fillings and coronal restorations. J Endod. 2009 Jun;35(6):810-3. https://doi.org/10.1016/i.joen.2009.03.048

7. Peters $O A$, Schönenberger K, Laib A. Effects of four $\mathrm{Ni}$-Ti preparation techniques on root canal geometry assessed by micro computed tomography. Int Endod J. 2001 Apr;34(3):221-30. https://doi.org/10.1046/i.1365-2591.2001.00373.x

8. Vera J, Siqueira Junior JF, Ricucci D, Loghin S, Fernández N, Flores B et al. One- versus two-visit endodontic treatment of teeth with apical periodontitis: a histobacteriologic study. J Endod. 2012 Aug;38(8):1040-52. https://doi.org/10.1016/i.joen.2012.04.010 
- Unprepared root canal surface areas: causes, clinical implications, and therapeutic strategies

9. Siqueira Junior JF, Araújo MC, Garcia PF, Fraga RC, Dantas CJ. Histological evaluation of the effectiveness of five instrumentation techniques for cleaning the apical third of root canals. J Endod. 1997 Aug;23(8):499-502. https://doi.org/10.1016/S0099-2399(97)80309-3

10. Walton RE. Histologic evaluation of different methods of enlarging the pulp canal space. J Endod. 1976 Oct;2(10):304-11. https://doi.org/10.1016/S0099-2399(76)80045-3

11. Mizrahi SJ, Tucker JW, Seltzer S. A scanning electron microscopic study of the efficacy of various endodontic instruments. J Endod. 1975 Oct;1(10):324-33. https://doi.org/10.1016/S0099-2399(75)80012-4

12. Pérez AR, Alves FRF, Marceliano-Alves MF, Provenzano JC, Gonçalves LS, Neves AA, Siqueira Junior JF. Effects of increased apical enlargement on the amount of unprepared areas and coronal dentin removal: a micro-computed tomography study. Int Endod J. 2018 Jun;51(6):684-90. https://doi.org/10.1111/iej.12873

13. Roane JB, Sabala CL, Duncanson Junior MG. The "balanced force" concept for instrumentation of curved canals. J Endod. 1985 May;11(5):203-11. https://doi.org/10.1016/S0099-2399(85)80061-3

14. Paqué F, Ganahl D, Peters $O A$. Effects of root canal preparation on apical geometry assessed by microcomputed tomography. J Endod. 2009 Jul;35(7):1056-9. https://doi.org/10.1016/j.joen.2009.04.020

15. Versiani MA, Leoni GB, Steier L, De-Deus G, Tassani $S$, Pécora JD et al. Micro-computed tomography study of oval-shaped canals prepared with the selfadjusting file, Reciproc, WaveOne, and ProTaper universal systems. J Endod. 2013 Aug;39(8):1060-6. https://doi.org/10.1016/j.joen.2013.04.009

16. Siqueira Junior JF, Alves FR, Versiani MA, Rôças IN, Almeida $B M$, Neves MA et al. Correlative bacteriologic and microcomputed tomographic analysis of mandibular molar mesial canals prepared by self-adjusting file, reciproc, and twisted file systems. J Endod. 2013 Aug;39(8):1044-50. https://doi.org/10.1016/j.joen.2013.04.034

17. Paqué $F$, Balmer $M$, Attin T, Peters OA. Preparation of oval-shaped root canals in mandibular molars using nickel-titanium rotary instruments: a micro-computed tomography study. J Endod. 2010 Apr;36(4):703-7. https://doi.org/10.1016/j.joen.2009.12.020

18. Yin X, Cheung GS, Zhang C, Masuda YM, Kimura Y, Matsumoto K. Micro-computed tomographic comparison of nickel-titanium rotary versus traditional instruments in C-shaped root canal system. J Endod. 2010 Apr;36(4):708-12. https://doi.org/10.1016/i.joen.2010.01.003

19. Amoroso-Silva P, Alcalde MP, Hungaro Duarte MA, DeDeus G, Ordinola-Zapata R, Freire LG et al. Effect of finishing instrumentation using $\mathrm{NiTi}$ hand files on volume, surface area and uninstrumented surfaces in C-shaped root canal systems. Int Endod J. 2017 Jun;50(6):604-11. https://doi.org/10.1111/iej.12660

20. Cheung LH, Cheung GS. Evaluation of a rotary instrumentation method for $\mathrm{C}$-shaped canals with microcomputed tomography. J Endod. 2008 Oct;34(10):1233-8. https://doi.org/10.1016/i.joen.2008.07.015

21. Solomonov M, Paqué F, Fan B, Eilat Y, Berman LH. The challenge of $C$-shaped canal systems: a comparative study of the self-adjusting file and ProTaper. J Endod. 2012 Feb;38(2):209-14. https://doi.org/10.1016/i.joen.2011.10.022

22. Paqué $F$, Zehnder M, De-Deus G. Microtomography-based comparison of reciprocating single-file F2 ProTaper technique versus rotary full sequence. J Endod. 2011 Oct;37(10):1394-7. https://doi.org/10.1016/j.joen.2011.06.031

23. Markvart M, Darvann TA, Larsen P, Dalstra $M$, Kreiborg S, Biørndal L. Micro-CT analyses of apical enlargement and molar root canal complexity. Int Endod J. 2012 Mar;45(3):273-81. https://doi.org/10.1111/j.1365-2591.2011.01972.x

24. Peters $O A$, Arias A, Paqué F. A micro-computed tomographic assessment of root canal preparation with a novel instrument, TRUShape, in mesial roots of mandibular molars. J Endod. 2015 Sep;41(9):1545-50. https://doi.org/10.1016/i.joen.2015.06.007

25. Peters $O A$, Laib A, Göhring TN, Barbakow F. Changes in root canal geometry after preparation assessed by high-resolution computed tomography. J Endod. 2001 Jan;27(1):1-6. https://doi.org/10.1097/00004770-200101000-00001

26. Yang G, Yuan G, Yun X, Zhou X, Liu B, Wu H. Effects of two nickel-titanium instrument systems, Mtwo versus ProTaper universal, on root canal geometry assessed by microcomputed tomography. J Endod. 2011 Oct;37(10):1412-6. https://doi.org/10.1016/i.joen.2011.06.024

27. Zhao D, Shen Y, Peng B, Haapasalo M. Root canal preparation of mandibular molars with 3 nickeltitanium rotary instruments: a micro-computed tomographic study. J Endod. 2014 Nov;40(11):1860-4. https://doi.org/10.1016/i.joen.2014.06.023

28. Gergi R, Osta N, Bourbouze G, Zgheib C, Arbab-Chirani $R$, Naaman $A$. Effects of three nickel titanium instrument systems on root canal geometry assessed by microcomputed tomography. Int Endod J. 2015 Feb;48(2):162-70. https://doi.org/10.1111/iej.12296

29. Limoeiro AGS, Santos AH, De Martin AS, Kato AS, Fontana CE, Gavini $G$ et al. Micro-computed tomographic evaluation of 2 nickel-titanium instrument systems in shaping root canals. J Endod. 2016 Mar;42(3):496-9. https://doi.org/10.1016/i.joen.2015.12.007

30. Alves FR, Andrade-Junior CV, Marceliano-Alves MF, Pérez $A R$, Rôças IN, Versiani MA et al. Adjunctive steps for disinfection of the mandibular molar root canal system: a correlative bacteriologic, micro-computed tomography, and cryopulverization approach. J Endod. 2016 Nov;42(11):166772. https://doi.org/10.1016/j.joen.2016.08.003 
31. Siqueira Junior JF, Pérez AR, Marceliano-Alves MF, Provenzano JC, Silva SG, Pires FR et ak. What happens to unprepared root canal walls: a correlative analysis using micro-computed tomography and histology/scanning electron microscopy. Int. Endod. J. 2018 May;51(5):501-8. https://doi.org/10.1111/iej.12753

32. Peters $\mathrm{OA}$, Peters $\mathrm{Cl}$, Schönenberger $\mathrm{K}$, Barbakow F. ProTaper rotary root canal preparation: effects of canal anatomy on final shape analysed by micro CT. Int Endod J. 2003 Feb;36(2):86-92. https://doi.org/10.1046/i.1365-2591.2003.00626.x

33. Paqué $F$, Barbakow $F$, Peters $O A$. Root canal preparation with Endo-Eze AET: changes in root canal shape assessed by microcomputed tomography. Int Endod J. 2005 Jul;38(7):456-64. https://doi.org/10.1111/j.1365-2591.2005.00968.x

34. Zhao D, Shen Y, Peng B, Haapasalo M. Micro-computed tomography evaluation of the preparation of mesiobuccal root canals in maxillary first molars with Hyflex CM, Twisted Files, and K3 instruments. J Endod. 2013 Mar;39(3):385-8. https://doi.org/10.1016/j.joen.2012.11.030

35. De-Deus G, Belladonna FG, Silva EJ, Marins JR, Souza EM, Perez $R$ et al. Micro-CT evaluation of non-instrumented canal areas with different enlargements performed by NiTi systems. Braz Dent J. 2015 Nov-Dec;26(6):624-9. https://doi.org/10.1590/0103-6440201300116

36. Gagliardi J, Versiani MA, Sousa-Neto MD, Plazas-Garzon A, Basrani B. Evaluation of the shaping characteristics of ProTaper Gold, ProTaper NEXT, and ProTaper Universal in curved canals. J Endod. 2015 Oct;41(10):1718-24. https://doi.org/10.1016/i.joen.2015.07.009

37. Brasil SC, Marceliano-Alves MF, Marques ML, Grillo JP, Lacerda MF, Alves FR et al. Canal transportation, unprepared areas, and dentin removal after preparation with bt-race and protaper next systems. J Endod. 2017 Oct;43(10):1683-7. https://doi.org/10.1016/i.joen.2017.04.012

38. Duque JA, Vivan RR, Cavenago BC, Amoroso-Silva PA, Bernardes RA, Vasconcelos BC et al. Influence of NiTi alloy on the root canal shaping capabilities of the ProTaper Universal and ProTaper Gold rotary instrument systems. J Appl Oral Sci. 2017 Jan-Feb;25(1):27-33. https://doi.org/10.1590/1678-77572016-0230

39. Busquim S, Cunha RS, Freire L, Gavini G, Machado ME, Santos M. A micro-computed tomography evaluation of long-oval canal preparation using reciprocating or rotary systems. Int Endod J. 2015 Oct;48(10):1001-6. https://doi.org/10.1111/iej.12398

40. Versiani MA, Pécora JD, Sousa-Neto MD. Flat-oval root canal preparation with self-adjusting file instrument: a microcomputed tomography study. J Endod. 2011 Jul;37(7):10027. https://doi.org/10.1016/i.joen.2011.03.017

41. Peters $O A$, Paqué $F$. Root canal preparation of maxillary molars with the self-adjusting file: a micro-computed tomography study. J Endod. 2011 Jan;37(1):53-7. https://doi.org/10.1016/i.joen.2010.08.047
42. Paqué F, Peters OA. Micro-computed tomography evaluation of the preparation of long oval root canals in mandibular molars with the self-adjusting file. J Endod. 2011 Apr;37(4):517-21. https://doi.org/10.1016/i.joen.2010.12.011

43. Stavileci M, Hoxha V, Görduysus Ö, Tatar I, Laperre K, Hostens $J$ et al. Evaluation of root canal preparation using rotary system and hand instruments assessed by microcomputed tomography. Med Sci Monit Basic Res. 2015 Jun;21:123-30. https://doi.org/10.12659/MSMBR.893950

44. Coelho BS, Amaral RO, Leonardi DP, Marques-da-Silva B, Silva-Sousa YT, Carvalho FM et al. Performance of Three Single Instrument Systems in the Preparation of Long Oval Canals. Braz Dent J. 2016 Mar-Apr;27(2):217-22. https://doi.org/10.1590/0103-6440201302449

45. Espir CG, Nascimento-Mendes CA, GuerreiroTanomaru JM, Freire LG, Gavini G, Tanomaru-Filho M. Counterclockwise or clockwise reciprocating motion for oval root canal preparation: a micro-CT analysis. Int Endod J. 2018 May;51(5):541-8. https://doi.org/10.1111/iej.12776

46. Zuolo ML, Zaia AA, Belladonna FG, Silva E, Souza EM, Versiani MA et al. Micro-CT assessment of the shaping ability of four root canal instrumentation systems in ovalshaped canals. Int Endod J. 2018 May;51(5):564-71. https://doi.org/10.1111/iej.12810

47. Guimarães LS, Gomes CC, Marceliano-Alves MF, Cunha RS, Provenzano JC, Siqueira Junior JF. Preparation of oval-shaped canals with TRUShape and Reciproc systems: a micro-computed tomography study using contralateral premolars. J Endod. 2017 Jun;43(6):1018-22. https://doi.org/10.1016/i.joen.2017.01.028

48. Arias A, Paqué F, Shyn S, Murphy S, Peters OA. Effect of canal preparation with TRUShape and Vortex rotary instruments on three-dimensional geometry of oval root canals. Aust Endod J. 2018 Apr;44(1):32-9. https://doi.org/10.1111/aej.12201

49. Lacerda MF, Marceliano-Alves MF, Pérez AR, Provenzano JC, Neves MA, Pires FR et al. Cleaning and shaping oval canals with 3 instrumentation systems: a correlative micro-computed tomographic and histologic study. J Endod. 2017 Nov;43(11):1878-84. https://doi.org/10.1016/i.joen.2017.06.032

50. McGurkin-Smith R, Trope M, Caplan D, Sigurdsson A. Reduction of intracanal bacteria using GT rotary instrumentation, $5.25 \% \mathrm{NaOCl}$, EDTA, and $\mathrm{Ca}(\mathrm{OH}) 2$. J Endod. 2005 May;31(5):359-63. https://doi.org/10.1097/01.don.0000145035.85272.7c

51. Shuping GB, Orstavik D, Sigurdsson A, Trope $M$. Reduction of intracanal bacteria using nickeltitanium rotary instrumentation and various medications. J Endod. 2000 Dec;26(12):751-5. https://doi.org/10.1097/00004770-200012000-00022

52. Sakamoto M, Siqueira JF Jr, Rôças IN, Benno Y. Bacterial reduction and persistence after endodontic treatment procedures. Oral Microbiol Immunol. 2007 Feb;22(1):19-23. https://doi.org/10.1111/j.1399-302X.2007.00315.x 
- Unprepared root canal surface areas: causes, clinical implications, and therapeutic strategies

53. Siqueira Junior JF, Paiva SS, Rôças IN. Reduction in the cultivable bacterial populations in infected root canals by a chlorhexidine-based antimicrobial protocol. J Endod. 2007 May;33(5):541-7. https://doi.org/10.1016/i.joen.2007.01.008

54. Neves MA, Rôças IN, Siqueira Junior JF. Clinical antibacterial effectiveness of the self-adjusting file system. Int Endod J. 2014 Apr;47(4):356-65. https://doi.org/10.1111/iej.12151

55. Rôças IN, Lima KC, Siqueira Junior JF. Reduction in bacterial counts in infected root canals after rotary or hand nickeltitanium instrumentation: a clinical study. Int Endod J. 2013 Jul;46(7):681-7. https://doi.org/10.1111/iej.12045

56. Zandi H, Rodrigues RC, Kristoffersen AK, Enersen M, Mdala I, Ørstavik D et al. Antibacterial effectiveness of 2 root canal irrigants in root-filled teeth with infection: a randomized clinical trial. J Endod. 2016 Sep;42(9):1307-13. https://doi.org/10.1016/j.joen.2016.06.006

57. Rodrigues RC, Zandi H, Kristoffersen AK, Enersen M, Mdala I, Ørstavik D, et al. Influence of the apical preparation size and the irrigant type on bacterial reduction in root canal-treated teeth with apical periodontitis. J Endod. 2017 Jul;43(7):1058-63. https://doi.org/10.1016/i.joen.2017.02.004

58. Siqueira Junior JF, Rôças IN, Favieri A, Lima KC. Chemomechanical reduction of the bacterial population in the root canal after instrumentation and irrigation with $1 \%, 2.5 \%$, and $5.25 \%$ sodium hypochlorite. J Endod. 2000 Jun;26(6):331-4. https://doi.org/10.1097/00004770-200006000-00006

59. Siqueira Junior JF, Rôças IN, Santos SR, Lima KC, Magalhães FA, Uzeda M. Efficacy of instrumentation techniques and irrigation regimens in reducing the bacterial population within root canals. J Endod. 2002 Mar;28(3):181-4. https://doi.org/10.1097/00004770-200203000-00009

60. Brito PR, Souza LC, Oliveira JCM, Alves FR, DeDeus G, Lopes HP, et al. Comparison of the effectiveness of three irrigation techniques in reducing intracanal Enterococcus faecalis populations: an in vitro study. J Endod. 2009 Oct;35(10):1422-7. https://doi.org/10.1016/i.joen.2009.07.001

61. Neves MA, Provenzano JC, Rôças IN, Siqueira Junior JF. Clinical antibacterial effectiveness of root canal preparation with reciprocating single-instrument or continuously rotating multi-instrument systems. J Endod. 2016 Jan;42(1):25-9. https://doi.org/10.1016/i.joen.2015.09.019

62. Rôças IN, Provenzano JC, Neves MA, Siqueira Junior JF. Disinfecting effects of rotary instrumentation with either $2.5 \%$ sodium hypochlorite or $2 \%$ chlorhexidine as the main irrigant: a randomized clinical study. J Endod. 2016 Jun;42(6):943-7. https://doi.org/10.1016/j.joen.2016.03.019

63. Siqueira Junior JF, Guimarães-Pinto T, Rôças IN. Effects of chemomechanical preparation with $2.5 \%$ sodium hypochlorite and intracanal medication with calcium hydroxide on cultivable bacteria in infected root canals. J Endod. $2007 \mathrm{Jul} ; 33(7): 800$ -

5. https://doi.org/10.1016/i.joen.2006.11.023

64. Siqueira Junior JF, Rôças IN, Paiva SS, Guimarães-Pinto T, Magalhães KM, Lima KC. Bacteriologic investigation of the effects of sodium hypochlorite and chlorhexidine during the endodontic treatment of teeth with apical periodontitis. Oral Surg Oral Med Oral Pathol Oral Radiol Endod. 2007 Jul;104(1):12230. https://doi.org/10.1016/i.tripleo.2007.01.027

65. Kvist T, Molander A, Dahlén G, Reit C. Microbiological evaluation of one- and two-visit endodontic treatment of teeth with apical periodontitis: a randomized, clinical trial. J Endod. 2004 Aug;30(8):572-6 https://doi.org/10.1097/01.DON.0000121607.87969.6E

66. Paquette $L$, Legner M, Fillery ED, Friedman S. Antibacterial efficacy of chlorhexidine gluconate intracanal medication in vivo. J Endod. 2007 Jul;33(7):788-95. https://doi.org/10.1016/i.joen.2005.12.017

67. Siqueira Junior JF, Magalhães KM, Rôças IN. Bacterial reduction in infected root canals treated with $2.5 \% \mathrm{NaOCl}$ as an irrigant and calcium hydroxide/camphorated paramonochlorophenol paste as an intracanal dressing. J Endod. 2007 Jun;33(6):667-72. https://doi.org/10.1016/i.joen.2007.01.004 PMID:17509403

68. Rôças IN, Siqueira Junior JF. In vivo antimicrobial effects of endodontic treatment procedures as assessed by molecular microbiologic techniques. J Endod. 2011 Mar;37(3):304-10. https://doi.org/10.1016/i.joen.2010.11.003

69. Rôças IN, Siqueira Junior JF. Comparison of the in vivo antimicrobial effectiveness of sodium hypochlorite and chlorhexidine used as root canal irrigants: a molecular microbiology study. J Endod. 2011 Feb;37(2):143-50. https://doi.org/10.1016/i.joen.2010.11.006

70. Rôças IN, Siqueira Junior JF. Identification of bacteria enduring endodontic treatment procedures by a combined reverse transcriptase-polymerase chain reaction and reverse-capture checkerboard approach. J Endod. 2010 Jan;36(1):45-52. https://doi.org/10.1016/i.joen.2009.10.022

71. Paiva SS, Siqueira Junior JF, Rôças IN, Carmo FL, Ferreira DC, Curvelo JA et al. Supplementing the antimicrobial effects of chemomechanical debridement with either passive ultrasonic irrigation or a final rinse with chlorhexidine: a clinical study. J Endod. 2012 Sep;38(9):1202-6. https://doi.org/10.1016/i.joen.2012.06.023

72. Huffaker SK, Safavi K, Spangberg LS, Kaufman B. Influence of a passive sonic irrigation system on the elimination of bacteria from root canal systems: a clinical study. J Endod. 2010 Aug;36(8):1315-8. https://doi.org/10.1016/i.joen.2010.04.024

73. Wu MK, Sluis LW, Wesselink PR. The capability of two hand instrumentation techniques to remove the inner layer of dentine in oval canals. Int Endod J. 2003 Mar;36(3):218-24. https://doi.org/10.1046/j.1365-2591.2003.00646.x

74. Weiger R, ElAyouti A, Löst C. Efficiency of hand and rotary instruments in shaping oval root canals. J Endod. 2002 Aug;28(8):580-3. https://doi.org/10.1097/00004770-200208000-00004 
75. Barbizam JV, Fariniuk LF, Marchesan MA, Pecora JD, Sousa-Neto MD. Effectiveness of manual and rotary instrumentation techniques for cleaning flattened root canals. J Endod. 2002 May;28(5):365-6. https://doi.org/10.1097/00004770-200205000-00004

76. Elayouti A, Chu AL, Kimionis I, Klein C, Weiger R, Löst C. Efficacy of rotary instruments with greater taper in preparing oval root canals. Int Endod J. 2008 Dec;41(12):1088-92. https://doi.org/10.1111/j.1365-2591.2008.01475.x

77. Taha NA, Ozawa T, Messer HH. Comparison of three techniques for preparing oval-shaped root canals. J Endod. 2010 Mar;36(3):532-5. https://doi.org/10.1016/i.joen.2009.11.015

78. De-Deus G, Barino B, Zamolyi RQ, Souza E, Fonseca Junior $A$, Fidel $S$ et al. Suboptimal debridement quality produced by the single-file F2 ProTaper technique in ovalshaped canals. J Endod. 2010 Nov;36(11):1897-900. https://doi.org/10.1016/j.joen.2010.08.009

79. Paqué F, Laib A, Gautschi H, Zehnder M. Hard-tissue debris accumulation analysis by high-resolution computed tomography scans. J Endod. 2009 Jul;35(7):1044-7. https://doi.org/10.1016/i.joen.2009.04.026

80. Versiani MA, Alves FR, Andrade-Junior CV, Marceliano-Alves MF, Provenzano JC, Rôças IN et al. Micro-CT evaluation of the efficacy of hard-tissue removal from the root canal and isthmus area by positive and negative pressure irrigation systems. Int Endod J. 2016 Nov;49(11):1079-87. https://doi.org/10.1111/iej.12559

81. De-Deus G, Marins J, Silva EJ, Souza E, Belladonna $F G$, Reis $C$ et al. Accumulated hard tissue debris produced during reciprocating and rotary nickel-titanium canal preparation. J Endod. 2015 May;41(5):676-81. https://doi.org/10.1016/i.joen.2014.11.028

82. Zuolo ML, Walton RE, Imura N. Histologic evaluation of three endodontic instrument/preparation techniques. Endod Dent Traumatol. 1992 Jun;8(3):125-9. https://doi.org/10.1111/j.1600-9657.1992.tb00449.x

83. Fornari VJ, Silva-Sousa YT, Vanni JR, Pécora JD, Versiani MA, Sousa-Neto MD. Histological evaluation of the effectiveness of increased apical enlargement for cleaning the apical third of curved canals. Int Endod J. 2010 Nov;43(11):988-94. https://doi.org/10.1111/j.1365-2591.2010.01724.x

84. Hülsmann M, Rümmelin C, Schäfers F. Root canal cleanliness after preparation with different endodontic handpieces and hand instruments: a comparative SEM investigation. J Endod. 1997 May;23(5):301-6. https://doi.org/10.1016/S0099-2399(97)80410-4

85. Schäfer E, Zapke K. A comparative scanning electron microscopic investigation of the efficacy of manual and automated instrumentation of root canals. J Endod. $2000 \mathrm{Nov} ; 26(11): 660-4$. https://doi.org/10.1097/00004770-200011000-00007

86. Schneider SW. A comparison of canal preparations in straight and curved root canals. Oral Surg Oral Med Oral Pathol. 1971 Aug;32(2):271-5. https://doi.org/10.1016/0030-4220(71)90230-1
87. Sydney GB, Batista A, Melo LL. The radiographic platform: a new method to evaluate root canal preparation in vitro. J Endod. 1991 Nov;17(11):570-2. https://doi.org/10.1016/S0099-2399(06)81724-3

88. Saleh AM, Gilani PV, Tavanafar S, Schäfer E. Shaping ability of 4 different single-file systems in simulated S-shaped canals. J Endod. 2015 Apr;41(4):548-52. https://doi.org/10.1016/j.joen.2014.11.019

89. Svec TA, Wang MM. The effect of instrument precurving on transportation in simulated curved canals. J Endod. 1998 Feb;24(2):122-4. https://doi.org/10.1016/S0099-2399(98)80091-5

90. Mamede-Neto I, Borges AH, Guedes OA, Oliveira D, Pedro FL, Estrela C. Root canal transportation and centering ability of nickel-titanium rotary instruments in mandibular premolars assessed using cone-beam computed tomography. Open Dent J. 2017 Feb;11(1):71-8. https://doi.org/10.2174/1874210601711010071

91. Nair PN, Henry S, Cano V, Vera J. Microbial status of apical root canal system of human mandibular first molars with primary apical periodontitis after "one-visit" endodontic treatment. Oral Surg Oral Med Oral Pathol Oral Radiol Endod. 2005 Feb;99(2):231-52. https://doi.org/10.1016/i.tripleo.2004.10.005

92. Siögren U, Figdor D, Persson S, Sundqvist G. Influence of infection at the time of root filling on the outcome of endodontic treatment of teeth with apical periodontitis. Int Endod J. 1997 Sep;30(5):297-306. https://doi.org/10.1111/j.1365-2591.1997.tb00714.x

93. Vianna ME, Horz HP, Conrads G, Feres M, Gomes BP. Comparative analysis of endodontic pathogens using checkerboard hybridization in relation to culture. Oral Microbiol Immunol. 2008 Aug;23(4):282-90. https://doi.org/10.1111/j.1399-302X.2007.00425.x

94. Bystrom A, Claesson R, Sundqvist $G$. The antibacterial effect of camphorated paramonochlorophenol, camphorated phenol and calcium hydroxide in the treatment of infected root canals. Endod Dent Traumatol. 1985 Oct;1 (5):170-5. https://doi.org/10.1111/j.1600-9657.1985.tb00652.x

95. Waltimo TM, Orstavik D, Sirén EK, Haapasalo MP. In vitro susceptibility of Candida albicans to four disinfectants and their combinations. Int Endod J. 1999 Nov;32(6):421-9. https://doi.org/10.1046/i.1365-2591.1999.00237.x

96. Siqueira Junior JF. Treatment of endodontic infections. London: Quintessence Publishing; 2011. pp. 43-93.

97. Ricucci D, Siqueira Junior JF, Bate AL, Pitt Ford TR. Histologic investigation of root canal-treated teeth with apical periodontitis: a retrospective study from twentyfour patients. J Endod. 2009 Apr;35(4):493-502. https://doi.org/10.1016/i.joen.2008.12.014

98. Ricucci D, Siqueira Junior JF. Apical actinomycosis as a continuum of intraradicular and extraradicular infection: case report and critical review on its involvement with treatment failure. J Endod. 2008 Sep;34(9):1124-9. https://doi.org/10.1016/i.joen.2008.06.002 
99. Carr GB, Schwartz RS, Schaudinn C, Gorur A, Costerton JW. Ultrastructural examination of failed molar retreatment with secondary apical periodontitis: an examination of endodontic biofilms in an endodontic retreatment failure. J Endod. 2009 Sep;35(9):1303-9. https://doi.org/10.1016/i.joen.2009.05.035

100. Ricucci D, Siqueira Junior JF. Biofilms and apical periodontitis: study of prevalence and association with clinical and histopathologic findings. J Endod. 2010 Aug;36(8):127788. https://doi.org/10.1016/i.joen.2010.04.007

101. Ricucci D, Loghin S, Siqueira Junior JF. Exuberant Biofilm infection in a lateral canal as the cause of short-term endodontic treatment failure: report of a case. J Endod. 2013 May;39(5):712-8. https://doi.org/10.1016/i.joen.2012.12.008

102. Arnold M, Ricucci D, Siqueira Junior JF. Infection in a complex network of apical ramifications as the cause of persistent apical periodontitis: a case report. J Endod. 2013 Sep;39(9):1179-84. https://doi.org/10.1016/i.joen.2013.04.036

103. Nair PN, Siögren U, Krey G, Kahnberg KE, Sundqvist G. Intraradicular bacteria and fungi in root-filled, asymptomatic human teeth with therapy-resistant periapical lesions: a long-term light and electron microscopic follow-up study. J Endod. 1990 Dec;16(12):580-8. https://doi.org/10.1016/S0099-2399(07)80201-9

104. Vieira AR, Siqueira Junior JF, Ricucci D, Lopes WS. Dentinal tubule infection as the cause of recurrent disease and late endodontic treatment failure: a case report. J Endod. 2012 Feb;38(2):250-4. https://doi.org/10.1016/i.joen.2011.10.019

105. Siqueira Junior JF, Lima KC, Magalhães FA, Lopes HP, Uzeda M. Mechanical reduction of the bacterial population in the root canal by three instrumentation techniques. J Endod. 1999 May;25(5):332-5. https://doi.org/10.1016/S0099-2399(06)81166-0

106. Rollison S, Barnett F, Stevens RH. Efficacy of bacterial removal from instrumented root canals in vitro related to instrumentation technique and size. Oral Surg Oral Med Oral Pathol Oral Radiol Endod. 2002 Sep;94(3):366-71. https://doi.org/10.1067/moe.2002.126164

107. Mickel AK, Chogle S, Liddle J, Huffaker K, Jones JJ. The role of apical size determination and enlargement in the reduction of intracanal bacteria. J Endod. 2007 Jan;33(1):21-3. https://doi.org/10.1016/j.joen.2006.08.004

108. Card SJ, Sigurdsson A, Orstavik D, Trope M. The effectiveness of increased apical enlargement in reducing intracanal bacteria. J Endod. 2002 Nov;28(11):779-83. https://doi.org/10.1097/00004770-200211000-00008

109. Orstavik D, Kerekes K, Molven O. Effects of extensive apical reaming and calcium hydroxide dressing on bacterial infection during treatment of apical periodontitis: a pilot study. Int Endod J. 1991 Jan;24(1):1-7. https://doi.org/10.1111/j.1365-2591.1991.tb00863.x
110. Dalton BC, Orstavik D, Phillips C, Pettiette M, Trope M. Bacterial reduction with nickel-titanium rotary instrumentation. J Endod. 1998 Nov;24(11):763-7. https://doi.org/10.1016/S0099-2399(98)80170-2

111. Usman N, Baumgartner JC, Marshall JG. Influence of instrument size on root canal debridement. J Endod. 2004 Feb;30(2):110-2. https://doi.org/10.1097/00004770-200402000-00012

112. Albrecht LJ, Baumgartner JC, Marshall JG. Evaluation of apical debris removal using various sizes and tapers of ProFile GT files. J Endod. 2004 Jun;30(6):425-8. https://doi.org/10.1097/00004770-20040600000012PMID:15167472

113. Saini HR, Tewari S, Sangwan P, Duhan J, Gupta A. Effect of different apical preparation sizes on outcome of primary endodontic treatment: a randomized controlled trial. J Endod. 2012 Oct;38(10):1309-15. https://doi.org/10.1016/i.joen.2012.06.024

114. Aminoshariae A, Kulild JC. Master apical file size - smaller or larger: a systematic review of healing outcomes. Int Endod J. 2015 Jul;48(7):639-47. https://doi.org/10.1111/iej.12370

115. Rundquist BD, Versluis $A$. How does canal taper affect root stresses? Int Endod J. 2006 Mar;39(3):226-37. https://doi.org/10.1111/j.1365-2591.2006.01078.x

116. Paiva SS, Siqueira Junior JF, Rôças IN, Carmo FL, Leite $D C$, Ferreira DC et al. Clinical antimicrobial efficacy of $\mathrm{NiTi}$ rotary instrumentation with $\mathrm{NaOCl}$ irrigation, final rinse with chlorhexidine and interappointment medication: a molecular study. Int Endod J. 2013 Mar;46(3):225-33. https://doi.org/10.1111/j.1365-2591.2012.02111.x

117. Siqueira Junior JF, Rôças IN. Optimising single-visit disinfection with supplementary approaches: a quest for predictability. Aust Endod J. 2011 Dec;37(3):92-8. https://doi.org/10.1111/j.1747-4477.2011.00334.x

118. Azim AA, Aksel H, Zhuang T, Mashtare T, Babu JP, Huang GT. Efficacy of 4 irrigation protocols in killing bacteria colonized in dentinal tubules examined by a novel confocal laser scanning microscope analysis. J Endod. 2016 Jun;42(6):928-34. https://doi.org/10.1016/i.joen.2016.03.009

119. Huque J, Kota K, Yamaga M, Iwaku M, Hoshino E. Bacterial eradication from root dentine by ultrasonic irrigation with sodium hypochlorite. Int Endod J. 1998 Jul;31 (4):242-50. https://doi.org/10.1046/j.1365-2591.1998.00156.x

120. Siqueira Junior JF, Machado AG, Silveira RM, Lopes HP, Uzeda M. Evaluation of the effectiveness of sodium hypochlorite used with three irrigation methods in the elimination of Enterococcus faecalis from the root canal, in vitro. Int Endod J. $1997 \mathrm{Jul} ; 30(4): 279-82$. https://doi.org/10.1111/j.1365-2591.1997.tb00708.x

121. Alves FR, Almeida BM, Neves MA, Moreno JO, Rôças IN, Siqueira Junior JF. Disinfecting oval-shaped root canals: effectiveness of different supplementary approaches. J Endod. 2011 Apr;37(4):496-501. https://doi.org/10.1016/i.joen.2010.12.008 
122. Tardivo D, Pommel L, La Scola B, About I, Camps J. Antibacterial efficiency of passive ultrasonic versus sonic irrigation. Ultrasonic root canal irrigation. Odontostomatol Trop. 2010 Mar;33(129):29-35.

123. Paiva SS, Siqueira JF Jr, Rôças IN, Carmo FL, Leite DC, Ferreira DC et al. Molecular microbiological evaluation of passive ultrasonic activation as a supplementary disinfecting step: a clinical study. J Endod. 2013 Feb;39(2):190-4. https://doi.org/10.1016/i.joen.2012.09.014

124. Rodrigues RC, Antunes HS, Neves MA, Siqueira Junior JF, Rôças IN. Infection control in retreatment cases: in vivo antibacterial effects of 2 instrumentation systems. J Endod. 2015 Oct;41(10):1600-5. https://doi.org/10.1016/j.joen.2015.06.005

125. Liang $Y H$, Jiang $L M$, Jiang L, Chen XB, Liu YY, Tian FC et al. Radiographic healing after a root canal treatment performed in single-rooted teeth with and without ultrasonic activation of the irrigant: a randomized controlled trial. J Endod. 2013 Oct;39(10):1218-25. https://doi.org/10.1016/i.joen.2013.06.024

126. Zamany A, Safavi K, Spångberg LS. The effect of chlorhexidine as an endodontic disinfectant. Oral Surg Oral Med Oral Pathol Oral Radiol Endod. 2003 Nov;96(5):57881. https://doi.org/10.1016/S1079-2104(03)00168-9

127. De-Deus G, Souza EM, Barino B, Maia J, Zamolyi RQ, Reis $C$ et al. The self-adjusting file optimizes debridement quality in oval-shaped root canals. J Endod. 2011 May;37(5):701-5. https://doi.org/10.1016/i.joen.2011.02.001

128. Siqueira Junior JF, Alves FR, Almeida BM, Oliveira JC, Rôças IN. Ability of chemomechanical preparation with either rotary instruments or self-adjusting file to disinfect oval-shaped root canals. J Endod. 2010 Nov;36(11):1860-5. https://doi.org/10.1016/i.joen.2010.08.001

129. Ribeiro MVM, Silva-Sousa YT, Versiani MA, Lamira A, Steier $L$, Pécora JD et al. Comparison of the cleaning efficacy of self-adjusting file and rotary systems in the apical third of oval-shaped canals. J Endod. 2013 Mar;39(3):398-401. https://doi.org/10.1016/i.joen.2012.11.016

130. Metzger Z, Teperovich E, Cohen R, Zary R, Paqué $F$, Hülsmann M. The self-adjusting file (SAF). Part 3: removal of debris and smear layer-A scanning electron microscope study. J Endod. 2010 Apr;36(4):697-702. https://doi.org/10.1016/i.joen.2009.12.037

131. Pawar R, Alqaied A, Safavi K, Boyko J, Kaufman B. Influence of an apical negative pressure irrigation system on bacterial elimination during endodontic therapy: a prospective randomized clinical study. J Endod. 2012 Sep;38(9):1177-81. https://doi.org/10.1016/i.joen.2012.06.013

132. Fabricius L, Dahlén G, Sundqvist G, Happonen RP, Möller AJ. Influence of residual bacteria on periapical tissue healing after chemomechanical treatment and root filling of experimentally infected monkey teeth. Eur J Oral Sci. 2006 Aug;114(4):27885. https://doi.org/10.1111/j.1600-0722.2006.00380.x
133. Waltimo T, Trope M, Haapasalo M, Ørstavik D. Clinical efficacy of treatment procedures in endodontic infection control and one year follow-up of periapical healing. J Endod. 2005 Dec;31(12):863-6. https://doi.org/10.1097/01.don.0000164856.27920.85

134. Heling B, Shapira J. Roentgenologic and clinical evaluation of endodontically treated teeth, with or without negative culture. Quintessence Int Dent Dig. 1978 Nov;9(11):79-84.

135. Engström B, Hard AF, Segerstad L, Ramström G, Frostell G. Correlation of positive cultures with the prognosis for root canal treatment. Odontol Revy. 1964;15(3):257-70.

136. Kayaoglu G, Erten H, Alaçam T, Ørstavik D. Shortterm antibacterial activity of root canal sealers towards Enterococcus faecalis. Int Endod J. 2005 Jul;38(7):483-8. https://doi.org/10.1111/j.1365-2591.2005.00981.x

137. Siqueira Junior JF, Gonçalves RB. Antibacterial activities of root canal sealers against selected anaerobic bacteria. J Endod. 1996;22(2):89-90. https://doi.org/10.1016/S0099-2399(96)80277-9.

138. Siqueira Junior JF, Favieri A, Gahyva SM, Moraes SR, Lima KC, Lopes HP. Antimicrobial activity and flow rate of newer and established root canal sealers. J Endod. 2000 May;26(5):274-7. https://doi.org/10.1097/00004770-200005000-00005

139. Orstavik D. Antibacterial properties of root canal sealers, cements and pastes. Int Endod J. 1981 May;14(2):125-33. https://doi.org/10.1111/j.1365-2591.1981.tb01073.x

140. Siqueira Junior JF, Rôças IN, Favieri A, Abad EC, Castro AJ, Gahyva SM. Bacterial leakage in coronally unsealed root canals obturated with 3 different techniques. Oral Surg Oral Med Oral Pathol Oral Radiol Endod. 2000 Nov;90(5):64750. https://doi.org/10.1067/moe.2000.110412

141. Shipper G, Trope M. In vitro microbial leakage of endodontically treated teeth using new and standard obturation techniques. J Endod. 2004 Mar;30(3):154-8. https://doi.org/10.1097/00004770-200403000-00007

142. Khayat A, Lee SJ, Torabinejad M. Human saliva penetration of coronally unsealed obturated root canals. J Endod. 1993 Sep;19(9):458-61. https://doi.org/10.1016/S0099-2399(06)80533-9

143. Torabinejad M, Ung B, Kettering JD. In vitro bacterial penetration of coronally unsealed endodontically treated teeth. J Endod. 1990 Dec;16(12):566-9. https://doi.org/10.1016/S0099-2399(07)80198-1

144. Chailertvanitkul P, Saunders WP, Mackenzie D. An assessment of microbial coronal leakage in teeth root filled with gutta-percha and three different sealers. Int Endod J. 1996 Nov;29(6):387-92. https://doi.org/10.1111/j.1365-2591.1996.tb01403.x

145. Hollanda AC, Estrela CR, Decurcio DA, Silva JA, Estrela C. Sealing ability of three commercial resin-based endodontic sealers. Gen Dent. 2009 Jul-Aug;57(4):368-73. 